\title{
Genetic Engineering of Field, Industrial and Pharmaceutical Crops
}

\author{
Hari P. Singh, Bharat P. Singh \\ Agricultural Research Station, Fort Valley State University, Fort Valley, GA, USA \\ Email: singhh@fvsu.edu
}

Received 1 October 2014; revised 2 November 2014; accepted 3 December 2014

Copyright (C) 2014 by authors and Scientific Research Publishing Inc.

This work is licensed under the Creative Commons Attribution International License (CC BY).

http://creativecommons.org/licenses/by/4.0/

(c) (i) Open Access

\begin{abstract}
Ability to modify plants at the genomic level by advanced molecular technology has enhanced the scope of improvements in plant traits attempted earlier through conventional breeding methods. Techniques such as genetic transformation have opened new vistas whereby functional genes, not commonly present in a particular species can be added from other species. The traits incorporated into the genetically engineered plants in the beginning were confined to those governed by dominant genes, e.g. insecticide resistance and herbicide tolerance but advancements with time now also permit the transfer of complexly inherited traits such as drought and cold tolerance. Transgenic technology is also useful in understanding gene expression and metabolic pathways which can then be used to harness the full genomic potential of the plant. This review presents a narrative on development of transgenics and their use for the improvement of field, industrial and pharmaceuticals crops. In addition, discussions are made on current status on genetically modified crops, hurdles to genetic engineering, overcoming strategies and future scope.
\end{abstract}

\section{Keywords}

Genetic Engineering (GE), Transgenic, Genetically Modified (GM), Field Crops, Industrial Crops, Pharmaceutical Crops, Molecular Farming

\section{Introduction}

The alteration or modification in an organism's genome using modern DNA technology is called genetic engineering or genetic modification. Since it involves the introduction of foreign DNA or synthetic genes into the organism of interest the resulting artifact is often referred as transgenic and or genetically modified (GM). The ability to introduce alien genes from distant species or life forms into plants has made available an entirely new and novel gene resource pool to breeders in their pursuit to improve crops for survival, productivity, and products. Transgenic crops can be generated with the use of recombinant DNA techniques which alter the crop's ge- 
netic makeup by manipulating the genome-either by introduction, deletion, substitution, or silencing of an individual gene or group of genes of interest. The functionality of transgenes has expanded with time. In the beginning, only traits that exhibited complete dominance, free of the interaction from the native plant genome or the environment, were targeted. For such traits, only one copy of the trait introduced into one of the inbred parents was required. Fortunately, some of these dominant traits such as insect resistance and herbicide tolerance provided solution to major production hurdles encountered by farmers in producing major crops of food and fiber.

Cultural practice modification offered by early transgenic varieties not only enhanced economic return to the farmer because of higher crop yields but also had multiplier effects of soil erosion prevention from reduced tillage, and reduction in environmental pollution from the residual herbicides and insecticides. Now, the scope of transgenic technology has expanded to include quantitative traits such as stress tolerance and yield improvement that necessitate the interaction of the introgressed genes with native genes engaged in the metabolic pathway for the phenotypic trait expression where environment may also influence considerably the final phenotypic expression. Stacking of introgressed genes in hybrids to create value combination of traits is also receiving considerable attention. Genetic engineering (GE) is usually resorted when improvement through conventional breeding and mutagenesis have been exhausted. Such situations arise if a desired trait is not present in the crop germplasm, the trait has proven difficult or very time consuming to improve through conventional breeding, or there is a need to remove or switch off particular genes. Commercialization of first genetically engineered crop started back in 1996 and since then it has reached new heights in its application and wide adaptability to various sectors of modern agriculture. Since 1996 to 2013 there has been tremendous increase in the acreage of genetically engineered crops. Between 1996 and 2013 there has been more than 100 fold increase in the acreage of genetically engineered crops [1].

\section{Development of Transgenic}

The ability of genetic engineering to incorporate foreign traits into plants was first exhibited in 1970s. Although approved earlier for limited sale, it was not until 1996 that the Monsanto Company (USA) got the approval to commercially market European corn borer (Ostrinia nubilalis) resistant corn (Zea mays L.), Colorado potato beetle (Leptinotarsa decemlineata) resistant potato (Solanum tuberosum L.), cotton bollworm complex (tobacco budworm-Heliothis virescence, bollworm-Helicoverpa zea, and pink bollworm-Pectinophora gossypiell) resistant cotton (Gossypium hirsutum L.), and a non-selective, broad spectrum herbicide glyphosate (N-phosphonomethylglycine) tolerant soybean (Glycine max (L.) Merr.). The genes for all insecticidal proteins, modified $c r y 1 A b$ in corn [2], modified $c r y 1 A c$ in cotton [3], and modified cry3Ab in potato [4] derived from commonly found soil bacteria—Bacillus thuringiensis $(B t)$. Glyphosate tolerant soybean was developed by incorporating a bacterium glyphosate resistant EPSP (5-enolpyruvyl shikimate-3-phosphate) synthase gene [5]. The transgenic crop research developed over years can be grouped into three generations (Figure 1). Each generation represents unique thrust areas for developing transgenic crops and has contributed to the present pool of commercially adopted transgenic crops [6].

Modern agriculture has been quick to adopt the commercial first generation transgenic crops expressing herbicide tolerance and insect resistance since these effects were clearly visible in the crop production systems. The second generation transgenic crops were designed for product quality characteristics but they did not lived up to expectations, and no commercial crop with these specific characteristics is presently in the market. However, the first approved transgenic food, Calgene's Flavr Savr tomato which reached the market in 1994, succeeded in delaying softening of the ripe fruit after harvesting but was a complete commercial failure and was withdrawn from the market in 1997 out of safety concerns. The third generation of transgenic crops has been engineered for use as biofactories or living reactors in the production of pharmaceuticals and industrial chemicals and is often referred as "molecular farming".

\section{Genetic Engineering of Crops}

The early and most cost-reward producing use of GE has been in the development of insecticide and pesticide resistance in field crops. A great deal of interest has currently been shown in incorporating tolerance to environmental stresses in crop cultivars in order to stabilize the yield under fluctuating environmental conditions. In 


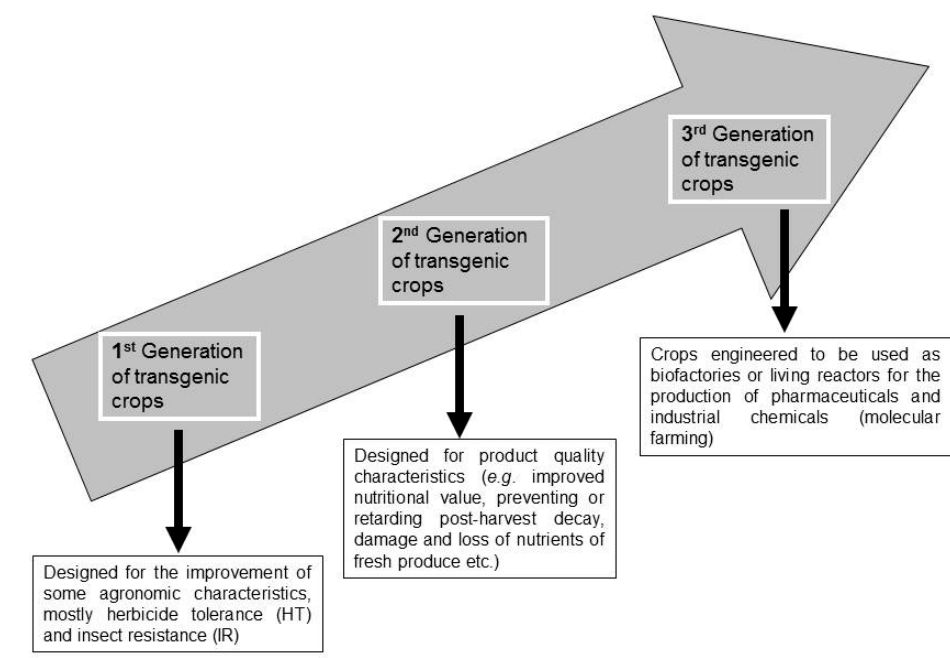

\begin{tabular}{llll}
\hline 1995 & 2000 & 2005 & 2013
\end{tabular}

Figure 1. Development and characterization of genetically engineered crops.

addition, as enhanced nutritive value of crop has gathered much interest to combat malnutrition in developing countries and to meet the food preference of naturalists, several transgenic cultivars with fortified nutritive values have been released. Some degree of success has also been accomplished in developing crops with chemical constituent of industrial value and the use of plants as hosts for pharmaceutical products.

\subsection{Field Crops}

Similar to the wide acceptance of hybrid corn due to its yield advantage more than sixty years ago, farmers in the United States now commonly plant transgenic cultivars of several field crops possessing traits that increase their value or yield potential. The typical transgenic traits approved for US crops are herbicide tolerance (bromoxynil, glufosinate, glyphosate, sulfonylurea), insect resistance (Bt kurstaki, Bt tenebrionis), virus resistance (Papaya ringspot virus, cucumber mosaic virus, zucchini yellow mosaic virus, watermelon mosaic virus, potato leaf roll virus, potato virus Y), male sterility (barnase/barstar), modified ripening (ACC synthase, ACC deaminase, SAM hydrolase, polygalacturonase), and modified oils (high lauric, myristic, oleic acids) [7]. Currently, transgenic acreage in several countries (4 - 17 different countries) for soybean, cotton, maize and canola account for $79 \%, 70 \%, 32 \%$ and $24 \%$ respectively of the total planting [1]. Table 1 lists different transgenic cultivars have been released or are at different stages of development.

The transgenes currently employed in weed management confer resistance to crops allowing use of effective broad-spectrum herbicides. The gene characterizing bacterial enzyme conferring tolerance to glyphosate has been most widely used, however, transgenes conferring tolerance to bromoxynil (Buctril), glufosinate (Liberty), and sulfonylurea (Glean) are also registered [7]. Two classes of Cry genes from Bacillus thuringiensis have been incorporated to produce Cry protein in a number of plants species to control a lipidopteran and co-lipidopteran insects [7]. The protein breaks down in the insect intestine releasing a lethal toxin called delta-endotoxin. Duke [85] enumerated three strategies for alleviating the need for herbicidal kill utilizing transgenes, namely, 1) transgenic alteration of biocontrol agents to make them more effective in managing weeds, 2) transgenes that produce a more competitive crop or provide the ability to produce natural phytotoxins (allelochemicals) and 3) cover crops that will self-destruct near the time of main crop planting alleviating the need for herbicidal kill. The disease resistances of commercial value have been incorporated into papaya (Carica papaya L.) to bestow resistance to papaya-ringspot-virus [86] and into rice (Oryza sativa L.) to give bacterial leaf blight resistance [87].

Most of phosphorus (P) in the soil is present in insoluble form limiting its availability to the plant. However, López et al. [88] observed that engineering to overproduce citrate enhanced the ability of tobacco (Nicotiana tabacum L.) plants to use insoluble $\mathrm{P}$ in the soil with potential for commercial utilization. Researchers are attempting to improve photosynthesis in $\mathrm{C}_{3}$ plants with the aim of boosting yield by achieving overexpression of 
$\mathrm{C}_{4}$-cycle enzymes [89]-[91] but much work remains to accomplish this goal. In a recent review [92], the potential of transgenic approach in improving rice production has been shown by identifying a range of traits that can be addressed to develop transgenic for commercial adoption and cultivation. Response of a plant to environmental stress can range from altered gene expression and cellular metabolism to changes in crop yields [93]. Genes have been introduced into cereals to fortify the grain nutritional value, e.g., cereals fortified with vitamin A to prevent partial or full blindness and with iron to relieve anemia due to iron deficiency in pregnant woman and children. Golden rice (Oryza sativa L.) is the result of the introduction of two genes from daffodils (Narcissus pseudonarcissus L.) and one from a microorganism resulting in increased production of vitamin A precursor beta-carotene [94]. Also in rice, genes involved in the production of an iron-binding protein and enzyme that facilitates its availability have been introduced to develop genotypes exhibiting elevated levels of iron [95]. Considerable amount of research has been devoted to enhance nutritive value of different crops with varied success. Researchers have also attempted to incorporate improved quality traits (delayed ripening, enhanced appearance, extended functionality, enhanced sweetness, and fats and oils) and nutritive value (fats and oils, protein, carbohydrate, caroteniod and vitamin E) into crops (Table 1).

Table 1. Selected examples of transgenic crops targeting a specific trait or quality for crop improvement.

\begin{tabular}{|c|c|c|c|c|}
\hline Scientific name & $\begin{array}{l}\text { Common } \\
\text { name }\end{array}$ & Trait/quality & Target gene product/gene/source & Reference \\
\hline Beta vulgaris & Sugar beet & $\begin{array}{l}\text { Herbicide tolerance } \\
\quad \text { (glyphosate) }\end{array}$ & $\begin{array}{l}\text { 5-Enolypyruvylshikimate-3-phosphate synthase (EPSPS), } \\
\text { CP4 strain of Agrobacterium tumefaciens }\end{array}$ & {$[8]$} \\
\hline Glycine max L. & Soybean & $\begin{array}{c}\text { Herbicide tolerance } \\
\text { (glufosinate ammonium) } \\
\text { Carotenoids and vitamin E } \\
\text { Fats and oil } \\
\text { Protein } \\
\text { Heat shock protein }\end{array}$ & $\begin{array}{c}\text { Phosphinothricin acetyltransferase (PAT), } \\
\text { Streptomyces viridochromogenes } \\
\text { Alpha-tocopherol } \\
\text { Omega-3-fatty acid; increased oleic acid } \\
\text { Methionine enriched glycinin } \\
\text { P5CR-Increased proline accumulation }\end{array}$ & $\begin{array}{l}\text { [10] } \\
{[11][12]} \\
{[13]} \\
{[14]}\end{array}$ \\
\hline $\begin{array}{l}\text { Gossypium } \\
\text { hirsutum L. }\end{array}$ & Cotton & $\begin{array}{l}\text { Insect-resistance } \\
\text { Increased ethanol } \\
\text { production }\end{array}$ & $\begin{array}{l}\text { cry1F gene, from Bacillus thuringiensis var Aizawa } \\
\text { ADH (Alcohol dehydrogenase) }\end{array}$ & $\begin{array}{l}{[15]} \\
{[16]}\end{array}$ \\
\hline $\begin{array}{l}\text { Helianthus } \\
\text { annuus }\end{array}$ & Sunflower & $\begin{array}{l}\text { Herbicide tolerance } \\
\text { (imidazolinone) } \\
\text { Fats and oil }\end{array}$ & $\begin{array}{c}\text { By selection of a naturally occurring mutant } \\
\text { Docosahexaenoic }\end{array}$ & $\begin{array}{l}{[17]} \\
{[18]}\end{array}$ \\
\hline Lens culinaris & Lentil & $\begin{array}{l}\text { Chemically induced } \\
\text { seed mutagenesis }\end{array}$ & Acetohydroxyacid synthase (AHAS) & {$[19]$} \\
\hline $\begin{array}{l}\text { Linum } \\
\text { usitatissimum L. }\end{array}$ & $\begin{array}{l}\text { Flax, } \\
\text { Linseed }\end{array}$ & $\begin{array}{l}\text { Herbicide tolerance } \\
\text { (sulfonylurea) }\end{array}$ & Acetolactate synthase (ALS) & {$[20]$} \\
\hline Brassica napus & $\begin{array}{l}\text { Argentine } \\
\text { Canola }\end{array}$ & $\begin{array}{l}\text { Herbicide tolerance } \\
\text { (glufosinate ammonium) }\end{array}$ & Phosphinothricin acetyltransferase (PAT), S. viridochromogenes & {$[21]$} \\
\hline $\begin{array}{l}\text { Medicago } \\
\text { sativa }\end{array}$ & Alfalfa & $\begin{array}{l}\text { Herbicide tolerance } \\
\text { (glyphosate) (lucerne) } \\
\text { Drought and freezing }\end{array}$ & $\begin{array}{l}\text { 5-Enolypyruvylshikimate-3-phosphate synthase (EPSPS), } \\
\text { CP4 strain of Agrobacterium tumefaciens } \\
\text { Sod, Mn-Sod, Mn superoxidase dismutase }\end{array}$ & $\begin{array}{l}{[22]} \\
{[23]} \\
{[24][25]}\end{array}$ \\
\hline Oryza sativa & Rice & $\begin{array}{l}\text { Herbicide tolerance } \\
\text { (imidazolinone, } \\
\text { imazethapyr) } \\
\text { Protein } \\
\text { Salinity and drought } \\
\text { Submergence tolerance } \\
\text { Cold tolerance } \\
\text { Metal toxicity tolerance }\end{array}$ & $\begin{array}{c}\text { Acetolactate synthase (ALS), ethyl methanesulfonate (EMS) } \\
\text { Beta-phaseolin } \\
\text { HVA 1 } \\
\text { pdc1, Sub1 } \\
\text { Wx-control amylase synthesis, Gs2-chloroplastic } \\
\text { glutamine synthetase } \\
\text { Par } \beta \text {-Glutathione S-transferase }\end{array}$ & $\begin{array}{l}{[26]} \\
{[27]} \\
{[28]} \\
{[29][30]} \\
{[31][32]} \\
{[33]}\end{array}$ \\
\hline $\begin{array}{l}\text { Triticum } \\
\text { aestivum }\end{array}$ & Wheat & $\begin{array}{l}\text { Herbicide tolerance } \\
\text { (imidazolinone) } \\
\text { Glyphosate tolerance } \\
\text { Enhanced functionality }\end{array}$ & $\begin{array}{c}\text { Acetohydroxyacid synthase (AHAS), ALS } \\
\text { 5-Enolpyruvylshikimate-3-phosphate synthase (EPSPS), } \\
\text { Agrobacterium tumefaciens, strain CP4 } \\
\text { Protein modification of high molecular weight glutenins, flour } \\
\text { functionality } \\
\text { DREB1A, HVA1 }\end{array}$ & $\begin{array}{c}{[34]} \\
{[35]} \\
{[36][37]} \\
{[38][39]} \\
{[40]} \\
{[41][42]}\end{array}$ \\
\hline
\end{tabular}




\section{Continued}

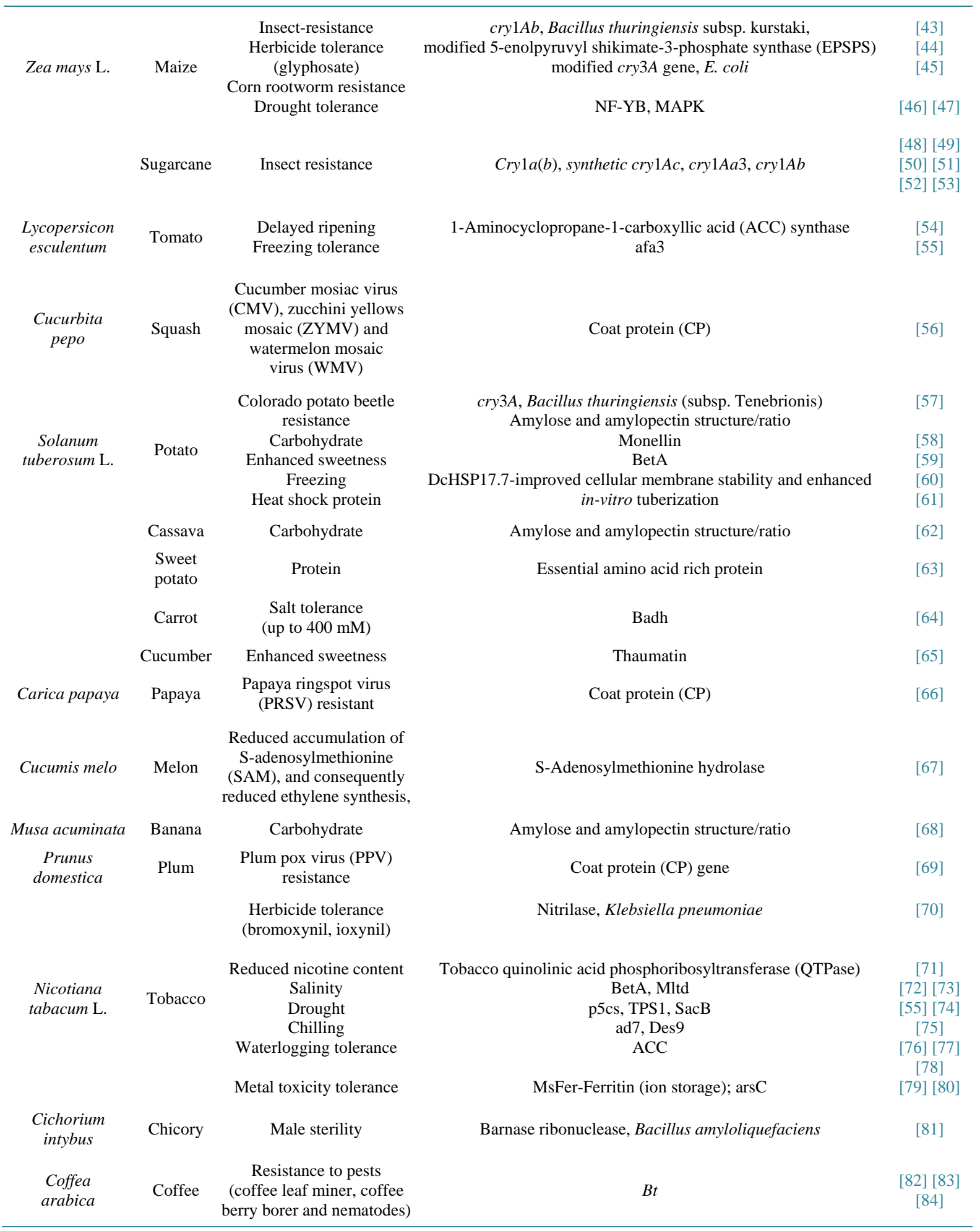

\subsection{Industrial Crops}

The crop grown as a feedstock in the production of a commodity rather than for direct human consumption is referred to as industrial crop. The industrial crops contribute to the farm income and provide economic stimulus 
to rural areas. The products from industrial crops also provide a pool of substitutes for classic imports from other nations. Some examples of industrial crops are: oil palm, rape seed, soybean, safflower, peas, plantago, potato, fiber hemp, flax, guar, agave, cassava, jojoba, kenaf. Fiber crops are amongst the most common industrial crops. Some transgenic plant lines, which produce compounds for specific industrial applications, are already commercialized, and many more are at different stages of development by biotechnology companies, research institutes and universities. Progress has been slow in developing transgenic plants for important industrial uses. However, immense potential exists in employing GE for producing crops for biofuel, pulp and paper, plastics, oil and lubricants, and soil remediation.

\subsubsection{Biofuel, Paper and Plastics}

Lignocellulosic biomass constitutes an important category of feedstock whose conversion into biofuel is accretive to the environment due to its high carbon sequestration credential. However, there is a major impediment to the process of conversion of the biomass cellulose to ethanol as it is embedded within the lignin of the plant cell walls and not easily separable for direct chemical reaction. This recalcitrance adds extra and cumbersome steps to the conversion process and the release of all cell wall cellulose for utilization remains problematic. Researchers have genetically engineered the switchgrass (Panicum virgatum) to address the recalcitrance and reduced ethanol yield [96]. Overexpression of PvMYB4, a general transcriptional repressor of the phenylpropanoid/lignin biosynthesis pathway, has shown promising results by increasing cellulosic ethanol yield from switchgrass by 2.6-fold and a dramatic reduction of recalcitrance [96]. Genetically engineered PvMYB4-OX switchgrass can thus provide a novel system for further understanding cell wall recalcitrance. Similar studies were done on transgenic alfalfa lines where it was found that recalcitrance to both acid pretreatment and enzymatic digestion is directly proportional to lignin content. Modifying the lignin biosynthetic enzymes yielded nearly twice as much sugar from cell walls as wild-type plants [97]. Lignin modification, by genetic engineering, could bypass the need for acid pretreatment and thereby facilitate bioprocess consolidation. Moreover, induction of genes that accelerates lignin degradation can be valuable for pulp and paper production from lignocellulosic biomass as well. Laccase (benzenediol: oxygen oxidoreductase, EC 1.10.3.2) enzyme present in white rot fungi has attracted much attention because of its ability to degrade lignin [98]. Hood et al. [99] generated transgenic maize plants by employing an Agrobacterium-mediated system with fungal laccase gene (EMBL accession no. U44430) which showed highest expression in the maize embryo-preferred globulin 1 promoter and targeting of the protein to the cell wall. High oil germplasm was used to increase germination, as well as to assist in increasing expression 20-fold in five generations through breeding and selection. It was hypothesized that the high oil lines might provide substrate (i.e. oil) for the laccase-generated free radicals to act upon, thereby preventing the accumulation of free radicals that alter seed physiology, such as increased lignification. Downregulation of one of the major enzymes involved in lignin biosynthesis, 4-coumarate: coenzyme A ligase (Pt4CL1) in transgenic aspen (Populus tremuloldes), resulted in a $45 \%$ decrease in lignin with a compensation of $15 \%$ increase in cellulose, doubling the plant cellulose:lignin ratio without any change in lignin composition and without any apparent harm to plant growth, development or structural integrity [100]. Changing levels of cinnamyl alcohol dehydrogenase (CAD) have also been found to modify lignin synthesis [101]. Poplar (Populus tremula $\times$ Populus $a l b a$ ) with CAD antisense constructs grows similar to control trees but with an increase in the proportion of free phenolic groups in lignin facilitating solubilization and fragmentation [102].

Poly 3-hydroxyalkanoates (PHAs) are a class of microbially produced polyesters comprising of at least 100 different PHA constituents and at least five different dedicated PHA biosynthetic pathways [103] with potential application as biodegradable plastics. Arai et al. [104] was able to transfer from Aeromonas caviae FA440 modified PHA synthase gene (phaCAc) into Arabidopsis thaliana that enabled the plant to accumulate PHA in its tissues.

\subsubsection{Industrially Desirable Fatty Acids}

Cahoon et al. [105] reported that expression of a gene from pot marigold encoding an enzyme that introduces conjugated double bonds into polyunsaturated fatty acids resulted in the accumulation of calendic acid, a novel conjugated polyunsaturated fatty acid, to amounts of $20 \%$ - $25 \%$ of the reported total soybean seed oil. Calendic acid is even more oxidatively unstable than linolenic acid, thus improving the drying properties of coating applications. However, the level of calendic acid concentration in soybean at $20 \%-25 \%$ remains much lower than $55 \%$ concentration found in the marigold. 
Castor (Ricinus communis L.) oil contains high levels (up to 90\%) of ricinoleic acid needed for conversion to substitutes for petroleum derived lubricants, emulsifiers, inks, and nylons. Unfortunately, castor cultivation is prohibited in most countries as the seeds also contain toxin ricin. The level of ricinoleic acid achieved in tobacco and Arabidopsis have been only to the amount of $<1 \%$ and 17\%, respectively [97] [98] [106] [107]. Singh et al. [108] observed that although a single gene (FAH12) may regulate ricinoleic acid synthesis, its accumulation in triglycerol most likely required involvement of other genes. Napier [109] noted that, thus far, it has been difficult to attain levels of industrially desirable fatty acids in transgenic plants similar to found in the non-agronomic source plants.

McKeon [110] reported the ongoing efforts to enhance industrial chemical constituents in important crops. Canola with high laurate for detergent and soybean with high oleate for food and monomers have reached commercial stage, while canola with petroselenate for food and monomers, soybean with vernolate for plasticizers and coatings, cotton with low-saturates for food uses are in development.

\subsubsection{Phytoremediation}

There are many reports of transgenic plants exhibiting tolerance to varying levels of heavy metals, a trait useful for phytoremediation of contaminated soils [111]-[118]. Arabidopsis thaliana transformed by type 2 MT (met-

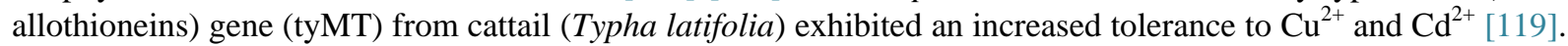
Indian mustard (Brassica juncea) plants overexpressing ATP sulphurylase were shown to have higher shoot Se concentrations and enhanced Se tolerance compared to wild type when grown in the presence of selenite [120] [121]. Family of sulfur rich peptides termed phytochelatins (PCs) are able to bind to Cd and some other heavy metals [122] and transgenic tobacco plants over expressing cysteine synthase in either the cytosol or chloroplasts were more tolerant to metals such as Cd, Se and Ni [123]. Transgenic plants have been developed with altered transporter genes with the aim to exclude a toxic metal ion, transporting the metal into the apoplastic space and vacuole where metal would be less likely to exert a toxic effect [124]. Phytoremediation uses different plant processes and mechanisms normally involved in the accumulation, complexation, volatilization, and degradation of organic and inorganic pollutants [125]. Table 2 shows categorization of different processes used by some of the model transgenic plants in phytoremediation. Most of the information available today is either from laboratory and or greenhouse experiments. Elaborated field testing is required to validate and establish the effectiveness of these transgenic plants for actual cleanup of contaminated metal sites.

\subsection{Pharmaceutical Crops}

Genetic transformation studies have shown the potential of producing recombinant proteins, including pharmaceuticals and industrial proteins, and other secondary metabolites in plants. Several substances have already been produced in transgenic plants and are in different stages of clinical trials (Table 3) but none of them were approved as pharmaceutical for humans until 2012. Recently, an enzyme, for treating the rare hereditary Gaucher disease (Elelyso, developed by Protalix) generated in carrot tissue became the first Plant Made Pharmaceutical (PMP) for human use to gain regulatory approval by the US FDA [140]. At present, many crops are being developed to produce drugs or biologics for the diagnosis, treatment, or prevention of diseases in human and animals. These include enzymes, hormones, anticoagulant factors, vaccines, and monoclonal antibodies targeted at a variety of disease, such as cystic fibrosis or non-Hodgkin's lymphoma [141].

Current therapeutic proteins biosynthesis systems utilizing prokaryotes, yeasts and cultured mammalian cell mediums are handicapped in several ways [142]. Prokaryotes can only biosynthesize simple therapeutic proteins such as insulin, interferon or growth hormone as complex proteins produced in them are not always properly folded or processed for proper level of biological activity [143]. Complex proteins produced from yeasts have co- and post-translational modifications (PTMs) problems while cultured mammalian cells are difficult to scale up to large volume productions due to lack of bioreactor capacities, high operating cost, and are subject to virus or prion contamination [138]. Recent studies have suggested transgenic plants could be suitable alternatives for large scale, low cost, and safe production of complex therapeutic mammalian proteins [144]. A range of plant/ crop species have been used in production of commercial pharma/crop products. An extensive review by Saklani and Kutty [145] describes the status on plant derived compounds in clinical trials with a special emphasis on plant-based anticancer drugs.

Using plants as bioreactor can substantially alleviate capacity problem especially in cases of therapeutic 
Table 2. Selected example of transgenic plants overexpressing genes for improved phytoextraction and phytovolatilization efficiency and phytodegradation potential.

\begin{tabular}{|c|c|c|c|c|}
\hline Target plant & Gene & Product/source & Performance & Reference \\
\hline \multicolumn{5}{|c|}{ Phytoextraction efficiency } \\
\hline Tobacco, rapeseed & MT2 & Metallothionein_-human & Enhanced Cd tolerance & {$[126]$} \\
\hline $\begin{array}{l}\text { Tobacco, } \\
\text { cauliflower }\end{array}$ & MT1 & Metallothionein-mouse & $\begin{array}{c}\text { Tolerated } 200 \mathrm{mM} \mathrm{CdCl}_{2} \\
\text { Tolerated } 400 \mathrm{mM} \mathrm{CdCl} \text { in hydroponic medium }\end{array}$ & $\begin{array}{l}{[127]} \\
{[128]}\end{array}$ \\
\hline Arabidopsis & PsMTA & Metallothionein-pea & $8 \times$ higher $\mathrm{Cu}$ accumulation & {$[129]$} \\
\hline Indian mustard & gshl & $\begin{array}{l}\gamma \text {-Glutamyl-cystein } \\
\quad(\text { E. coli })\end{array}$ & $\begin{array}{c}3 \text { - 5× higher } \gamma \text {-ECS and GSH levels and } 90 \% \text { higher shoot Cd } \\
\text { concentrations }\end{array}$ & {$[130]$} \\
\hline Poplar & gshI & $\begin{array}{l}\gamma \text {-Glu-cys synthetase } \\
\quad(E . \text { coli })\end{array}$ & Cd tolerance and increase of total sulfur in shoot & {$[131]$} \\
\hline \multicolumn{5}{|c|}{ Phytovolatilization efficiency } \\
\hline Arabidopsis & merB & $\begin{array}{l}\text { Organomecurial } \\
\text { lyase-bacteria }\end{array}$ & Volatilization of up to $763 \mathrm{ng} \mathrm{Hg}(0) \mathrm{min}^{-1} \cdot \mathrm{g}^{-1}$ & {$[132]$} \\
\hline Yellow poplar & merApe9 & $\begin{array}{l}\text { Hg(II) reductase- } \\
\text { mutagenized merA }\end{array}$ & Volatilization of $10 \times$ more mercury than WT plants & {$[133]$} \\
\hline Indian mustard & SMT & $\begin{array}{l}\text { Selenocysteine } \\
\text { methyltransferase } \\
\text { A. bisulcatus }\end{array}$ & $\begin{array}{l}\text { Volatilized } 2.5 \times \text { more Se than WT plants when } \\
\text { supplied with selenate }\end{array}$ & {$[134]$} \\
\hline \multicolumn{5}{|c|}{ Phytodegdration potential } \\
\hline Tobacco & Onr & PETN reductase & Enhanced detoxification of nitroglycerin & {$[135]$} \\
\hline Poplar & gshl & $y$-ECS & Elevated herbicide tolerance and rapid herbicide degradation & {$[136]$} \\
\hline Indian mustard & gshI and gshII & $y$-ECS and GS & $\begin{array}{l}\text { Enhanced tolerance and } 2-12 \times \text { increase } \\
\text { in nonprotein thiol level }\end{array}$ & {$[137]$} \\
\hline Rice, Potato & P450CYP & Mammalian cytochrome & $\begin{array}{l}\text { Enhanced detoxification and cross tolerance } \\
\text { toward several herbicides }\end{array}$ & {$[138][139]$} \\
\hline
\end{tabular}

Table 3. Plant made pharmaceuticals for human use at different stages of regulatory approval.

\begin{tabular}{|c|c|c|c|c|c|c|}
\hline Product & Crop & Class & Application & Status & Organization & Reference \\
\hline $\begin{array}{c}\text { Glucocerebrosidase } \\
\text { ELELYSO/UPLYSO }\end{array}$ & $\begin{array}{l}\text { Carrot cell } \\
\text { culture }\end{array}$ & $\begin{array}{c}\text { Therapeutic } \\
\text { enzyme }\end{array}$ & Gaucher's disease & $\begin{array}{c}\text { US FDA approved, } \\
\text { May, } 2012\end{array}$ & Protalix & {$[165]$} \\
\hline $\begin{array}{c}\text { Alpha-galactosidase } \\
\text { (PRX-102) }\end{array}$ & $\begin{array}{l}\text { Carrot cell } \\
\text { culture }\end{array}$ & $\begin{array}{c}\text { Therapeutic } \\
\text { enzyme }\end{array}$ & Fabry's disease & Phase I/II & Protalix & [166] \\
\hline $\begin{array}{l}\text { Acetylcholesterase } \\
\text { (PRX-105) }\end{array}$ & $\begin{array}{l}\text { Carrot cell } \\
\text { culture }\end{array}$ & $\begin{array}{c}\text { Therapeutic } \\
\text { enzyme }\end{array}$ & Biodefense & Phase I & Protalix & [167] \\
\hline Apo-A1Milano & Safflower & $\begin{array}{c}\text { Therapeutic } \\
\text { protein }\end{array}$ & $\begin{array}{c}\text { Cardiovascular } \\
\text { disease }\end{array}$ & Preclinical & $\begin{array}{l}\text { SemiBioSys } \\
\text { Genetics }\end{array}$ & [168] \\
\hline Human serum albumin & Flax & $\begin{array}{c}\text { Therapeutic } \\
\text { protein }\end{array}$ & $\begin{array}{c}\text { Maintenance of blood } \\
\text { plasma pressure }\end{array}$ & Preclinical & Agragen & [169] \\
\hline
\end{tabular}

antibodies production where rapid volume increases are of paramount concern. Plants also provide a wide array of species suited for use as bioreactors. A recombinant protein yield of up to $20 \mathrm{~kg} /$ ha have been reported using tobacco, corn, soybean or alfalfa [146] [147]. Newly developed plant expression systems in duckweed, moss, algae, and higher plant suspension-cultured cells offer the opportunity of fast turnover and high yield molecular farming in highly contained and completely controlled environment [142]. Unlike yeasts, transgenic plants possess the ability to carry out most PTMs needed to produce complex proteins such as plasma proteins, antigens, hormones, cytokines, enzymes and antibodies [144] [148]. In most cases, several PTMs including proteolytic cleavage(s), oligomerization and glycosylation are required to obtain therapeutic proteins of proper biological activity, pharmacokinetics, stability, and solubility [142]. Expression levels for therapeutic proteins in plants remain low and currently several approaches including codon optimization [149]-[151], RNA silencing [152] [153], targeted secretion of recombinant proteins by the roots [154] [155], stored into seed endosperm [156] and seed oilbodies [157], production in chloroplast [158] are being experimented to improve yields. Difference in 
the protein molecule $\mathrm{N}$-glycans produced by plants from mammalian glycoproteins may also trigger immune responses in humans and induce their fast clearance from the bloodstream [159] [160]. Strategies to obtain plant-derived antibodies with human-compatible carbohydrate profiles include their retention in the endoplasmic reticulum [161] [162] or alternatively transformation of plants with mammalian glycosyltransferase [163] [164]. As a result of these advances, plants have emerged as a potential safe and cost-effective alternative to microbial or mammalian expression systems especially for large quantity multimeric recombinant proteins.

\section{Current Status of Genetically Engineered Crops}

In the United States, the Animal and Plant Health Inspection Service (APHIS) regulates the development and release of transgenic crops. APHIS classifies phenotypic traits under AP (agronomic properties), BR (bacterial resistance), FR (fungal resistance), HT (herbicide tolerance), IR (insect resistance), MG (marker gene), NR (nematode resistance), OO (others), PQ (product quality), and VR (virus resistance) categories. APHIS issued a total of 2192 permits for different phenotypic traits in 2013. Other traits (OO), herbicide tolerance (HT) and agronomic properties (AP) topped the category by contributing 34.53, 21.94 and 20.12 percent [170] respectively (Figure 2). Permit for other traits also topped in year 2014 with more than $75 \%$ of total permit issued. One permit can contain multiple phenotypes of phenotype categories while each phenotype category may include one to several traits. The FAO data [171] on developing countries showed more than thousand different GMOs under various stages of commercialization (Table 4).

Since 1996 the increase in acreage of transgenic crops in industrial countries has moderated but the pace of planting these crops in developing countries has accelerated (Figure 3). The total area planted in genetically engineered crops has increased from 1.7 million hectares in 1996 to 175 million hectares in 2013 reflecting a remarkable increase global hectarage of genetically engineered crops by 100 folds. In 2013, transgenic crops were grown in a total of 27 countries where the top ten countries each grew more than 1 million hectares. A record 18 million farmers, in 27 countries, have planted 175 million hectares (432 million acres) in 2013 [1]. If a trend like this continues, it is expected that 40 or more countries will adopt genetically engineered crops by 2015 , the final year of the second decade of commercialization.

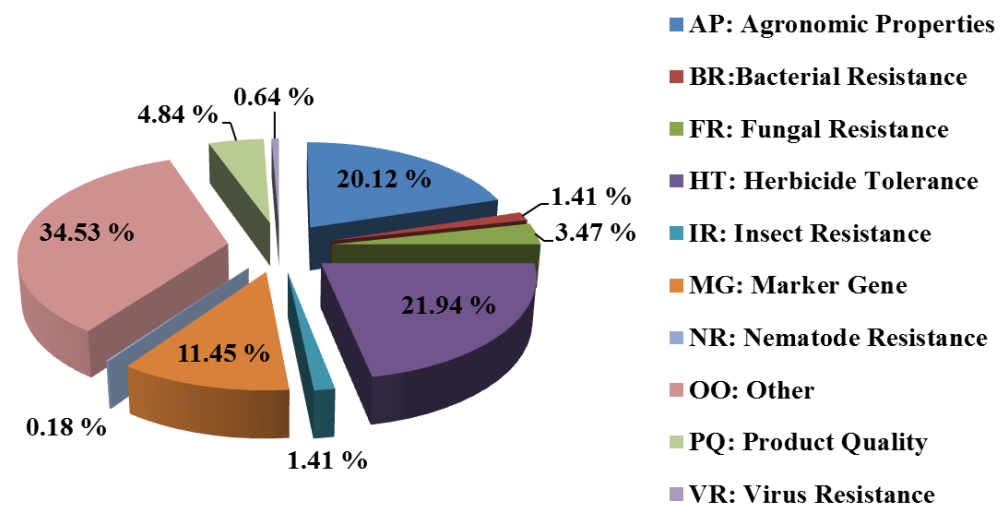

Figure 2. Total permits issued by phenotype for the transgenic crops in the United States during year 2013.

Table 4. Number of genetically modified organisms (GMOs) in developing countries under different stages of development.

\begin{tabular}{ccccc}
\hline Region/(GMOs) & Experimental phase & Field trial & Commercial phase & Not specified \\
\hline Asia (679) & 453 & 119 & 33 \\
Africa (85) & 39 & 36 & 10 & - \\
Latin America and Caribbean (306) & 99 & 185 & 6 & 2 \\
Europe (28) & 18 & 16 & 2 & 2 \\
Near East (51) & 31 & 640 & 362 & 62 \\
Grand total & 1149 & & & 85
\end{tabular}




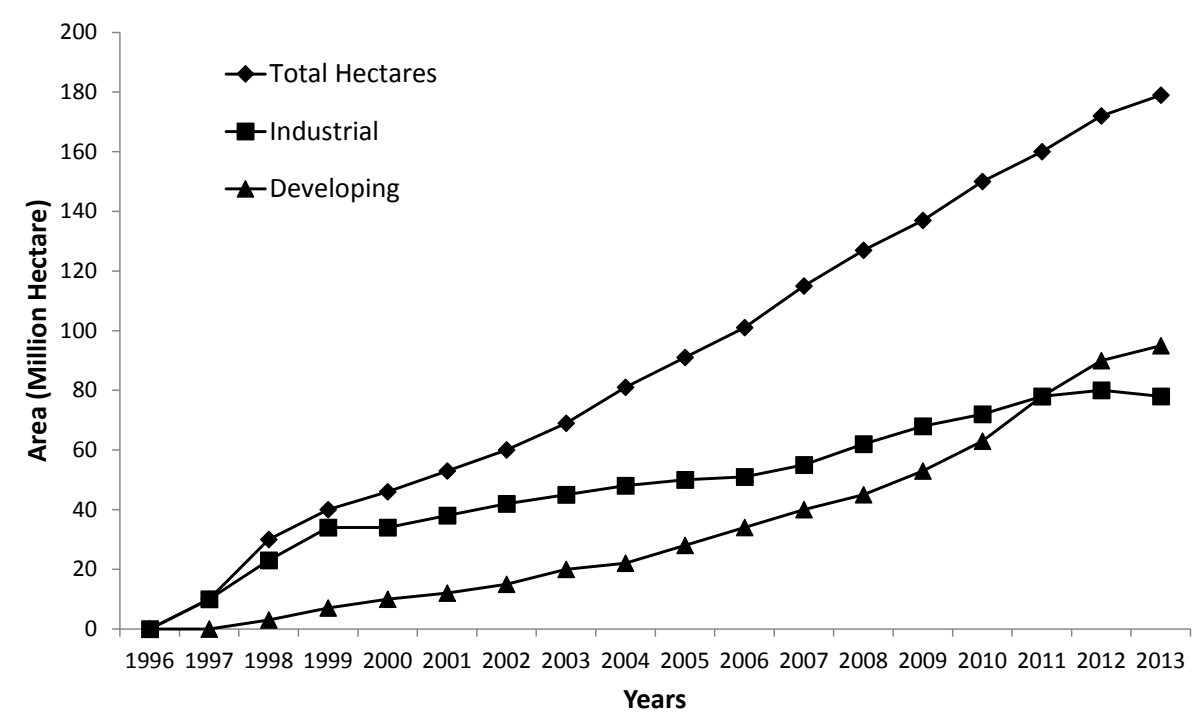

Figure 3. Trend of global growth in acreage of genetically engineered crop production between developing and industrial countries (adapted from Reference [1]).

\section{Hurdles to Genetic Engineering and Overcoming Strategies}

The rapid commercialization of transgenic technology is not without controversy. In addition to public suspicion or outright opposition, the main scientific concerns regarding deployment of transgenic crops include potential harmful effects to non-target organisms, gene flow into related wild species and persistence of gene products in the environment.

Transgenic technology is still in inception and faces a number of challenges. To start with, current methods of gene insertion are not precise to control the location and number of copies of the gene inserted. As the location has considerable influence on gene expression, if not placed suitably, "silencing" of the inserted gene can occur or inserted gene can silence the native genes. Transgenic traits are not always stable over generation and such instability could be deleterious to fertility, yield or other parameters of plant fitness or usefulness. Oftentimes, the inserted DNAs contain multiple stacked genes with the potential to cause undesirable interactions in the host plant. Pleiotropy is a common form of gene expression. Thus a gene known for a trait deemed desirable may produce unintended harmful side effects. King et al. [172] noted that glyphosate applied for weed control in soybean decreased biomass and seed yields when soil moisture was limiting.

There is fear that year-after year production of $B t$ crops will produce pest population resistant to cry proteins. This apprehension is appropriate as it has happened in the past after an insecticide was applied repetitively. The only way to overcome the threat from the acquired resistance by insects is to infuse into the plant new defense mechanism or build multiple barriers of defense. The incorporation of two $B t$ genes, cry $1 A c$ and cry $2 A b 2$ in cotton variety Bollgard II is an example of complex defense barrier through stacking of two resistance genes with different modes of action making it difficult for the pests to develop resistance to two proteins simultaneously. Eventually though, invasion of the barrier by the pests should be expected, and thus as with conventional breeding, transgenic breeding will also have to remain a continuous process.

The public and scientific debate on the long-term consequences of unnecessary DNA-sequences introduced into the plant during the transformation process continues. It is feared that widespread use of antibiotic-resistant genes for markers could lead to the evolution of bacterial varieties resistant to antibiotics. Hohn et al. [173] has reviewed strategies employed to eliminate selectable marker recombinant DNA-sequences from the transgenic plants. Zuo et al. [174] effectively removed marker genes from transgenic plants using the Cre/loxP site-specific recombinase. Some transformation systems, now, can be performed with any selectable marker systems [175].

Consumers rightfully should have a choice to consume or not to consume food grown out of transgenic crops. The separation of a crop produced by both transgenic and non-transgenic seeds on the same farm can be costly and bear chance of mix-up and resulting costly food recall similar to Starlink corn episode. Keenan and Stemmer [176] suggest transgene deletion from the food portion (grain, tuber) of the transgenic plants with appropri- 
ate recombinase to eliminate the need for identity preservation of food produced from non-transgenic crop varieties. The recombinase protein itself should also be rapidly degradable. Regulatory guidelines as to the acceptable level of transgenic DNA "residue" in food should assure the public safeguard.

There is also concern that pollen from a transgenic variety will drift and cross-fertilize the nontransgenic variety of the same crop in the vicinity or cross between herbicide resistant transgenics and related wild species will create "superweed". Ways to prevent transgene outflow could consist of measures to ensure its inheritance only through maternally derived genome by engineered male sterility or introduction of transgene into the chloroplast rather than nuclear genome [168] [169] [177] [178], but these techniques have potential pitfalls. Male sterility will cause problems for farmers intending to save seeds for the next crop. The transfer of $0.1 \%-0.5 \%$ of chloroplast traits via pollen [179] in tobacco as well as parental inheritance of chloroplast DNA in other higher plants has been observed [180] [181]. In addition, Huang et al. [182] observed that transgenes can migrate from the chloroplast to the nuclear genome. Singh et al. [183] described a strategy based on epigenetic inheritance (imprinting) and post-transcriptional gene silencing (PTGS)/RNA interference (RNAi) that would allow all seeds from self-pollinated transgenic plants to be harvested and re-sown, without the need for specific treatments, while retaining all of the transgenes present in the parent while preventing outcrossing via either male or female gametophyte.

\section{Future Scope}

The overall prospects of acceptance of transgenic crops and products will depend on positive public perception of this technology, especially as the agrobiotech industry complies with regulations, conducts rigorous research on biosafety and successfully completes field trials of these crops. Like any other newly developed technology, transgenic crop agrobiotechnology industry faces its own unique challenges and hurdles, especially relating to consumer concerns on health risks and environmental safety and barriers to world-wide trade. Long term effects of GE foods must be rigorously studied but guidelines and regulations for field-testing and marketing of GM products likewise must be clearly defined to remove ambiguity and potential law suits.

There are numerous technological challenges that must be overcome while attempting to introduce specific traits into a crop. Furthermore, the high cost (approximately US\$100 - 136 million [184] [185]) of developing and obtaining authorization for the commercialization of a transgenic event limits the development of transgenic crops only for selecting traits of wide interest. Agro-based companies like Monsanto, Dupont, Syngenta, Dow Agro, and Bayer Crop Science have daunting task of generating profit for share holders while they are also sensitive to the farming community and have a humanistic, consumer-oriented approach.

On positive note, numerous successes have been documented especially with regard to agronomic traits like herbicide resistance, pest resistance and drought tolerance. The high adoption rate of genetically engineered crops and controlled field trials and research in many developing countries and some EU countries are optimistic developments. The need to feed a growing world population, enhancing ability of crops to withstand climate change, and public preference for plant based industrial and pharmaceutical products should drive further research in GM plants and their production worldwide. Successful commercialization and marketing of transgenic crops and products would require mutual understanding and implementation of international standards and trade policies among nations.

\section{References}

[1] James, C. (2013) Global Status of Commercialized Biotech/GM Crops: 2013. ISAAA Brief No. 46, ISAAA, Ithaca, NY.

[2] Carozzi, N. and Koziel, M.G. (1997) Transgenic Maize Expressing a Bacillus thuringiensis Insecticidal Protein for Control of European Corn Borer. In: Carozzi, N. and Koziel, M.G., Eds., Advances in Insect Control: The Role of Transgenic Plants, Taylor and Francis, London, 63-74.

[3] Perlak, F.J., Deaton, R.W., Armstrong, T.A., Fuchs, R.L., Sims, S.S., Greenplate, J.T. and Fischhoff, D.A. (1990) Insect Resistant Cotton Plants. Nature Biotechnology, 8, 939-943. http://dx.doi.org/10.1038/nbt1090-939

[4] Perlak, F.J., Stone, T.B., Muskopf, Y.M., Peterson, L.J., Parker, G.B., McPherson, S.A., et al. (1993) Genetically Improved Potatoes: Protection from Damage by Colorado Potato Beetles. Plant Molecular Biology, 22, 313-321. http://dx.doi.org/10.1007/BF00014938

[5] Padgette, S.R., Kolacz, K.H., Delannay, X., Re, D.B., LaVallee, B.J., Tinius, C.N., et al. (1995) Development, Identi- 
fication, and Characterization of Glyphosate-Tolerant Soybean Line. Crop Science, 35, 1451-1461. http://dx.doi.org/10.2135/cropsci1995.0011183X003500050032x

[6] Naranjo, M.A. and Vicente, O. (2008) Transgenic Plants for the Third Millennium Agriculture. Bulletin of UASVM, Horticulture, 65, 38-43.

[7] Clark, D., Klee, H. and Dandekar, A. (2004) Despite Benefits, Commercialization of Transgenic Horticultural Crops Lags. California Agriculture, 58, 89-98. http://dx.doi.org/10.3733/ca.v058n02p89

[8] Monsanto (2004) http://ceragmc.org/index.php?action=gm_crop_database\&mode=ShowProd\&data=GTSB77\&frmat=LONG

[9] Bayer Crop Science (Aventis CropScience(AgrEvo) (1996) http://ceramc.org/index.php/GmCropDatabaseEvent/event/60

[10] Romer, S., Fraser, J., Kiano, C., Shipton, C., Misawa, W., Schuch, W. and Bramley, P.M. (2000) Elevation of the Provitamin A Content of Transgenic Tomato Plants. Nature Biotechnology, 18, 666-669. http://dx.doi.org/10.1038/76523

[11] Kinney, A.J. (1996) Designer Oils for Better Nutrition. Nature Biotechnology, 14, 946. http://dx.doi.org/10.1038/nbt0896-946

[12] Lui, K.S. and Brown, E.A. (1996) Enhancing Vegetable Oil Quality through Plant Breeding and Genetic Engineering. Food Technology, 50, 67-71.

[13] Kim, C.S., Kamiya, S., Sato, T., Utsumi, S. and Kito, M. (1990) Improvement of Nutritional Value and Functional Properties of Soybean Glycinin by Protein Engineering. Protein Engineering, Design and Selection, 3, 725-731. http://dx.doi.org/10.1093/protein/3.8.725

[14] Malik, M.K., Solvin, J.P., Hwang, C.H. and Zimmerman, J.L. (1999) Modified Expression of a Carrot Small Heat Shock Protein Genes, Hsp17.7, Results in Increased or Decreased Thermo Tolerance. Plant Journal, 20, 89-99. http://dx.doi.org/10.1046/j.1365-313X.1999.00581.x

[15] Dow Agro Sciences LLC (2004) http://ceragmc.org/index.php?action=gm_crop_database\&mode=ShowProd\&data=281-24-236

[16] Dennis, E.S., Dolferus, R., Ellis, M., Rahman, M., Wu, Y., Hoeren, F.U., et al. (2000) Molecular Strategies for Improving Waterlogging Tolerance in Plants. Journal of Experimental Botany, 51, 89-97. http://dx.doi.org/10.1093/jexbot/51.342.89

[17] BASF (2005)

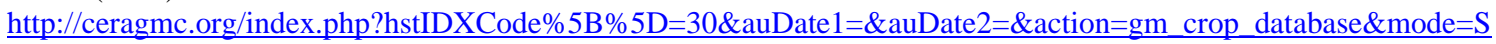
$\underline{\text { ubmit }}$

[18] Knutzon, D. (1999) Polyunsaturated Fatty Acids in Plants (International Patent Publication No. WO 99/64614, Date Filed: 6/10/1999). World Intellectual Property Organization, Geneva.

[19] BASF (2004) http://ceragmc.org/index.php?hstIDXCode\%5B\%5D=49\&auDate1=\&auDate2=\&action=gm_crop_database\&mode=S $\underline{\text { ubmit }}$

[20] University of Saskatchewan, Crop Dev. Centre (1999)

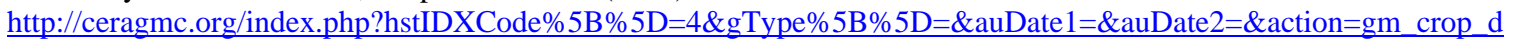
atabase \&mode $=$ Submit

[21] Bayer CropScience (Aventis CropScience(AgrEvo) (1998)

http://ceragmc.org/index.php?action=gm crop database\&mode=ShowProd\&data=T45+\%28HCN28\%29

[22] Monsanto (2004)

http://ceragmc.org/index.php?hstIDXCode\%5B\%5D=18\&auDate1=\&auDate2=\&action=gm_crop_database\&mode=S $\underline{\text { ubmit }}$

[23] Hightower, R., Baden, C., Penzes, E., Lund, P. and Dunsmuir, P. (1991) Expression of Antifreeze Proteins in Transgenic Plants. Plant Molecular Biology, 17, 1013-1021. http://dx.doi.org/10.1007/BF00037141

[24] McKersie, B.D., Bowley, S.R. and Jones, K.S. (1999) Winter Survival of Transgenic Alfalfa Overexpressing Superoxide Dismutase. Plant Physiology, 119, 839-848. http://dx.doi.org/10.1104/pp.119.3.839

[25] McKersie, B.D., Chen, Y., de Beus, M., Bowley, S.R., Bowler, C., Inze, D., D’Halluin, K. and Botterman, J. (1993) Superoxide Dismutase Enhances Tolerance for Freezing Stress in Transgenic Alfalfa (Medicago sativa L.). Plant Physiology, 103, 1155-1163. http://dx.doi.org/10.1104/pp.103.4.1155

[26] BASF (2002) http://ceragmc.org/index.php?action=gm_crop_database\&mode=ShowProd\&data=CL121\%2C+CL141\%2C+CFX51

[27] Zheng, A., Sumi, K., Tanaka, K. and Murai, N. (1995) The Bean Seed Storage Protein $\beta$-Phaseolin Is Synthesized, 
Processed and Accumulated in the Vacuolar Type-II Protein Bodies of Transgenic Rice Endosperm. Plant Physiology, 109, 777-786.

[28] Xu, D., Duan, X., Wang, B., Hong, B., Ho, T.H.D. and Wu, R. (1996) Expression of a Late Embryogenesis Abundant Protein Gene, HVA1, from Barley Confers Tolerance to Water Deficits and Salt Stress in Transgenic Rice. Plant Physiology, 110, 249-257.

[29] Qunimio, C.A., Torrizo, L.B., Setter, T.L., Ellis, M., Grover, A., Abrigo, E.M., et al. (2000) Enhancement of Submergence Tolerance in Transgenic Rice Overproducing Pyruvate Decarboxylase. Journal of Plant Physiology, 156, 516521. http://dx.doi.org/10.1016/S0176-1617(00)80167-4

[30] Xu, K., Xu, X., Fukao, T., Canlas, P., Maghirang-Rodriguez, R., Heuer, S., et al. (2006) Sub1A Is an Ethylene-Response-Factor-Like Gene that Confers Submergence Tolerance to Rice. Nature, 442, 705-708. http://dx.doi.org/10.1038/nature04920

[31] Hirano, H.Y. and Sano, Y. (1998) Enhancement of Wx Gene Expression and the Accumulation of Amylose in Response to Cool Temperatures during Seed Development in Rice. Plant \& Cell Physiology, 39, 807-812. http://dx.doi.org/10.1093/oxfordjournals.pcp.a029438

[32] Hoshida, H., Tanaka, Y., Hibino, T., Hayashi, Y., Tanaka, A. and Takabe, T. (2000) Enhance Tolerance to Salt Stress in Transgenic Rice over Expression Chloroplast Glutamine Synthetase. Plant Molecular Biology, 43, 103-111. http://dx.doi.org/10.1023/A:1006408712416

[33] Conway, G. and Toenniessen, G. (1999) Feeding the World in the Twenty-First Century. Nature, 402, C55-C58. http://dx.doi.org/10.1038/35011545

[34] BASF (2007) http://ceragmc.org/index.php?action=gm_crop_database\&mode=ShowProd\&data=BW7

[35] Monsanto (2004) http://ceragmc.org/index.php?action=gm_crop_database\&mode=ShowProd\&data=MON71800

[36] Shewry, P., Tatham, A., Barro, F., Barcelo, P. and Lazzeri, P. (1995) Biotechnology of Breadmaking: Unraveling and Manipulating the Multi-Protein Gluten Complex. Nature Biotechnology, 13, 1185-1190. http://dx.doi.org/10.1038/nbt1195-1185

[37] Blechl, A. and Anderson, O. (1996) Expression of a Novel High-Molecular-Weight Glutenin Subunit Gene in Transgenic Wheat. Nature Biotechnology, 14, 875-879. http://dx.doi.org/10.1038/nbt0796-875

[38] Barro, F., Rooke, L., Bekes, F., Gras, P., Tatham, F.R., Lazzeri, P., et al. (1997) Transformation of Wheat with High Molecular Weight Subunit Genes Results in Improved Functional Properties. Nature Biotechnology, 15, 1295-1299. http://dx.doi.org/10.1038/nbt1197-1295

[39] Shewry, P., Tatham, A. and Lazzeri, P. (1997) Biotechnology of Wheat Quality. Journal of the Science of Food and Agriculture, 73, 397-406. http://dx.doi.org/10.1002/(SICI)1097-0010(199704)73:4<397::AID-JSFA758>3.0.CO;2-Q

[40] Vasil, I. and Anderson, O. (1997) Genetic Engineering of Wheat Gluten. Trends in Plant Science, 2, 292-297. http://dx.doi.org/10.1016/S1360-1385(97)89950-5

[41] Pellegrineschi, A., Reynolds, M., Pacheco, M., Bitro, R.M., Almeraya, R., Yamaguchi-Shinazaki, K. and Hoisington, D. (2004) Stress Induced Expression in Wheat of the Arabidopsis thaliana DREB1A Gene Delays Water Stress Symptoms under Greenhouse Conditions. Genome, 47, 493-500. http://dx.doi.org/10.1139/g03-140

[42] Sivamani, E., Bahieldin, A., Wraith, J.M., Al-Niemi, T., Dyer, W.E., Ho, T.H.D. and Qu, R.D. (2000) Improved Biomass Productivity and Water Use Efficiency under Deficit Conditions in Transgenic Wheat Constitutively Expressing the Barley HVA1 Gene. Plant Science, 155, 1-9. http://dx.doi.org/10.1016/S0168-9452(99)00247-2

[43] Syngenta Seeds, Inc. (1995) http://ceragmc.org/index.php?action=gm crop database\&mode=ShowProd\&data=176

[44] Syngenta Seeds, Inc. (1996)

http://ceragmc.org/index.php?action=gm_crop_database\&mode=ShowProd\&data=GA21

[45] Syngenta Seeds, Inc. (2007) http://ceragmc.org/index.php?action=gm_crop_database\&mode=ShowProd\&data=MIR604

[46] Shou, H., Bordallo, P. and Wang, K. (2004) Expression of the Nicotiana Protein Kinase (NPK1) Enhanced Drought Tolerance in Transgenic Maize. Journal of Experimental Botany, 55, 1013-1019. http://dx.doi.org/10.1093/jxb/erh129

[47] Xiao, B.Z., Chen, X., Xiang, C.B., Tang, N., Zhang, Q.F. and Xiong, L.Z. (2009) Evaluation of Seven FunctionKnown Candidate Genes for Their Effects on Improving Drought Resistance of Transgenic Rice under Field Conditions. Molecular Plant, 2, 73-83. http://dx.doi.org/10.1093/mp/ssn068

[48] Arencibia, A., Vázquez, R.I., Prieto, D., Téllez, P., Carmona, E.R., Coego, A.H.L., et al. (1997) Transgenic Sugarcane Plants Resistant to Stem Borer Attack. Molecular Breeding, 3, 247-255. http://dx.doi.org/10.1023/A:1009616318854

[49] Braga, D.P.V., Arrigoni, E.D.B., Burnquist, W.L., Silva Filho, M.C., Ulian, E.C. and Hogarth, D.M. (2001) A New Approach for Control of Diatraea saccharalis (Lepidoptera: Crambidae) through the Expression of an Insecticidal 
CryIa(b) Protein in Transgenic Sugarcane. Proceedings of International Society of Sugarcane Technologists, 24, 331-336.

[50] Braga, D.P.V., Arrigoni, E.D.B., Silva Filho, M.C. and Ulian, E.C. (2003) Expression of the Cry1Ab Protein in Genetically Modified Sugarcane for the Control of Diatraea saccharalis (Lepidoptera: Crambidae). Journal of New Seeds, 5, 209-221. http://dx.doi.org/10.1300/J153v05n02_07

[51] Weng, L.X., Deng, H.H., Xu, J.L., Li, Q., Wang, L.H., Jiang, Z.D., et al. (2006) Regeneration of Sugarcane Elite Breeding Lines and Engineering of Strong Stem Borer Resistance. Pest Management Science, 62, 178-187. http://dx.doi.org/10.1002/ps.1144

[52] Kalunke, R.M., Kolge, A.M., Babu, K.H. and Prasad, D.T. (2009) Agrobacterium Mediated Transformation of Sugarcane for Borer Resistance Using Cry 1Aa3 Gene and One-Step Regeneration of Transgenic Plants. Sugar Tech, 11, 355-359. http://dx.doi.org/10.1007/s12355-009-0061-1

[53] Arvinth, S., Arun, S., Selvakesavan, R.K., Srikanth, J., Mukunthan, N., Kumar, P.A., et al. (2010) Genetic Transformation and Pyramiding of Aprotinin-Expressing Sugarcane with cry1Ab for Shoot Borer (Chilo infuscatellus) Resistance. Plant Cell Reports, 29, 383-395. http://dx.doi.org/10.1007/s00299-010-0829-5

[54] DNA Plant Technology Corporation (1994) http://ceragmc.org/index.php?action=gm_crop_database\&mode=ShowProd\&data=1345-4

[55] Kishor, P.B.K., Hong, Z., Miao, G.H., Hu, C.A. and Verma, D.P.S. (1995) Overexpression of $\delta$-Pyrroline-5-Carboxylate Synthetase Increases Proline Production and Confers Osmotolerance in Transgenic Plants. Plant Physiology, 108, 1387-1394.

[56] Asgrow (USA) Seminis Vegetable Inc. (1994) http://ceragmc.org/index.php?action=gm_crop_database\&mode=ShowProd\&data=CZW-3

[57] Monsanto (1996) http://cera-gmc.org/index.php?action=gm_crop_database\&mode=ShowProd\&data=ATBT04-6\%2C+ATBT04-27\%2C +ATBT04-30\%2C+ATBT04-31\%2C+ATBT04-36\%2C+SPBT02-5\%2C+SPBT02-7

[58] Visser, R., Somhorst, I., Kuipers, G., Ruys, N., Feenstra, W. and Jacobsen, E. (1991) Inhibition of the Expression of the Gene for Granule-Bound Starch Synthase in Potato by Antisense Constructs. Molecular and General Genetics, 225, 289-296. http://dx.doi.org/10.1007/BF00269861

[59] Pennarubia, L., Kim, R., Giovannoni, J., Kim, S. and Fischer, R. (1992) Production of the Sweet Protein Monellin in Transgenic Plants. Nature Biotechnology, 10, 561-564. http://dx.doi.org/10.1038/nbt0592-561

[60] Holmberg, N. and Bulow, L. (1998) Improving Stress Tolerance in Plants by Gene Transfer. Trends in Plant Science, $\mathbf{3}$, 61-66. http://dx.doi.org/10.1016/S1360-1385(97)01163-1

[61] Ahn, Y.J. and Zimmerman, L. (2006) Introduction of Carrot HSP17.7 into Potato (Solanum tuberosum L.) Enhances Cellular Membrane Stability and Tuberization in Vitro. Plant, Cell and Environment, 29, 95-104. http://dx.doi.org/10.1111/j.1365-3040.2005.01403.x

[62] Visser, R., Suurs, L., Steeneken, P. and Jacobsen, E. (1994) Some Physicochemical Properties of Amylose-Free Potato Starch. Starch/Stärke, 49, 443-448. http://dx.doi.org/10.1002/star.19970491104

[63] Katsube, T., Kurisaka, N., Ogawa, M., Maruyama, N., Ohtsuka, R., Utsumi, S. and Takaiwa, F. (1999) Accumulation of Soybean Glycinin and Its Assembly with Glutelins in Rice. Plant Physiology, 120, 1063-1074. http://dx.doi.org/10.1104/pp.120.4.1063

[64] Kumar, S., Dhingra, A. and Daniell, H. (2004) Plastid Expressed Betaine Aldehyde Dehydrogenase Gene in Carrot Cultured Cells, Roots and Leaves Confers Enhanced Salt Tolerance. Plant Physiology, 136, 2843-2854. http://dx.doi.org/10.1104/pp.104.045187

[65] Scwacka, M., Krzymowskab, M., Kowalczyk, M.E. and Osuch, A. (1999) Transgenic Cucumber Plants Expressing the Thaumatin Gene. In: Bielecki, S., Tramper, J. and Polak, J., Eds., Food Biotechnology. Proceedings of an International Symposium, Elsevier, Amsterdam, 43-48.

[66] Cornell University (1997) http://ceragmc.org/index.php?action=gm_crop_database\&mode=ShowProd\&data=55-1\%2F63-1

[67] Agritope Inc. (1999) http://ceragmc.org/index.php?hstIDXCode\%5B\%5D=16\&auDate1=\&auDate2=\&action=gm_crop_database\&mode=S ubmit

[68] Schwall, G., Safford, R., Westcott, R., Jeffcoat, A., Tayal, A., Shi, Y.C., et al. (2000) Production of Very-High-Amylose Potato Starch by Inhibition of SBE A and B. Nature Biotechnology, 18, 551-554.

http://dx.doi.org/10.1038/75427

[69] USDA (2009) 


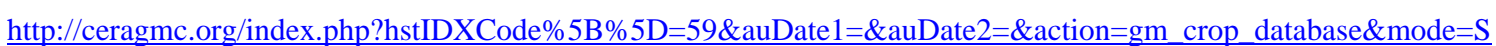
$\underline{\underline{\text { ubmit }}}$

[70] National Operating Company Tobacco and Matches (1999)

http://ceragmc.org/index.php?action=gm_crop_database\&mode=ShowProd\&data=C\%2FF\%2F93\%2F08-02

[71] Vector Tobacco Inc. (2002)

http://ceragmc.org/index.php?action=gm_crop_database\&mode=ShowProd\&data=Vector+21-41

[72] Lilius, G., Holmberg, N. and Bulow, L. (1996) Enhanced NaCl Stress Tolerance in Transgenic Tobacco Expressing Bacterial Choline Dehydrogenase. Nature Biotechnology, 14, 177-180. http://dx.doi.org/10.1038/nbt0296-177

[73] Tarczynski, M., Bohnert, H. and Jense, R.G. (1993) Stress Protection of Transgenic Tobacco by Production of the Osmolyte Mannitol. Science, 259, 508-510. http://dx.doi.org/10.1126/science.259.5094.508

[74] Holmstrom, K.O., Mantyla, E., Welin, B., Mandal, A., Palva, E.T., Tunnela, O.E. and Londesborough, J. (1996) Drought Tolerance in Tobacco. Nature, 379, 683-684. http://dx.doi.org/10.1038/379683a0

[75] Pilon-Smits, E.A.H., Ebskamp, M.J.M., Paul, M.J., Jeuken, M.J.W., Weisbeek, P.J. and Smeekens, S.C.M. (1995) Improved Performance of Transgenic Fructan-Accumulating Tobacco under Drought Stress. Plant Physiology, 107, $125-130$

[76] Murata, N., Sato, N., Takahashi, N. and Hamazaki, Y. (1982) Composition and Positional Distribution of Fatty Acids in Phospholipids from Leaves of Chilling Sensitive and Chilling Resistant Plants. Plant and Cell Physiology, 23, 10711079.

[77] Kodama, H., Hamada, T., Horiguchi, G., Nishimura, M. and Iba, K. (1994) Genetic Enhancement of Cold Tolerance by Expression of a Gene for Chloroplast-Fatty Acid Desaturase in Transgenic Tobacco. Plant Physiology, 105, 601-605.

[78] Grichko, V.P. and Glick, B.R. (2001) Flooding Tolerance of Transgenic Tomato Plants Expressing the Bacterial Enzyme ACC Deaminase Controlled by the 35S rolD or PRB-1b Promoter. Plant and Cell Physiology, 42, $245-249$.

[79] Deak, M., Horvarth, G.V., Davletova, S., Torok, K., Sass, L., Vass, I., et al. (1999) Plants Ectopically Expressing the Iron-Binding Protein Ferratin Are Tolerant to Oxidative Damage and Pathogen. Nature Biotechnology, 17, 192-196. http://dx.doi.org/10.1038/6198

[80] Dhankher, O.P., Shast, N.A., Rosen, B.P., Fuhrmann, M. and Meagher, R.B. (2003) Increased Cadmium Tolerance and Accumulation by Plants Expressing Bacterial Arsenate Reductase. New Phytologist, 159, 431-441. http://dx.doi.org/10.1046/j.1469-8137.2003.00827.x

[81] Bejo Zaden, B.V. (1997) http://ceragmc.org/index.php?hstIDXCode $\% 5 B \% 5 D=13 \& a u D a t e 1=\& a u D a t e 2=\& a c t i o n=$ gm_crop_database\&mode=S $\underline{\text { ubmit }}$

[82] Carneiro, M.F. (1997) Coffee Biotechnology and Its Application in Genetic Transformation. Euphytica, 96, 167-172. http://dx.doi.org/10.1023/A:1002969429010

[83] Santana-Buzzy, N., Rojas-Herrara, R., Galaz-Avalos, R.M., Ku-Cauich, J.R., Mijangos-Cortes, J., Gutierrez-Pancheco, L.C., et al. (2007) Advances in Coffee Tissue Culture and Its Practical Applications. In Vitro Cellular \& Developmental Biology-Plant, 43, 507-520. http://dx.doi.org/10.1007/s11627-007-9074-1

[84] Vega, F.E., Ebert, A.W. and Ming, R. (2008) Coffee Germplasm Resources, Genomics, and Breeding. Plant Breeding Reviews, 30, 415-447.

[85] Duke, S.O. (2003) Weeding with Transgenes. Trends in Biotechnology, 21, 192-195. http://dx.doi.org/10.1016/S0167-7799(03)00056-8

[86] Gonsalves, D. (1998) Control of Papaya Ringspot Virus in Papaya: A Case Study. Annual Review of Phytopathology, 36, 415-437. http://dx.doi.org/10.1146/annurev.phyto.36.1.415

[87] Zhai, W., Li, L.X., Tian, W., Zhou, Y., Pan, X., Cao, S., et al. (2000) Introduction of a Rice Blight Resistance Gene, Xa21, into Five Chinese Rice Varieties through an Agrobacterium-Mediated System. Science in China Series C, 43, 361-368. http://dx.doi.org/10.1007/BF02879300

[88] López-Bucio, J., de la Vega, O.M., Guevara-García, A. and Herrera-Estrella, L. (2000) Enhanced Phosphorous Uptake in Transgenic Tobacco Plants that Overproduce Citrate. Nature Biotechnology, 18, 450-453. http://dx.doi.org/10.1038/74531

[89] Häusler, R.E., Hirsch, H.J., Kreuzaler, F. and Peterhänsel, C. (2002) Overexpression of C $_{4}$-Cycle Enzymes in Transgenic $\mathrm{C}_{3}$ Plants: A Biotechnological Approach to Improve $\mathrm{C}_{3}$-Photosynthesis. Journal of Experimental Botany, 53, 591-607. http://dx.doi.org/10.1093/jexbot/53.369.591

[90] Leegood, R.C. (2002) $\mathrm{C}_{4}$ Photosynthesis: Principles of $\mathrm{CO}_{2}$ Concentration and Prospects for Its Introduction into $\mathrm{C}_{3}$ Plants. Journal of Experimental Botany, 53, 581-590. http://dx.doi.org/10.1093/jexbot/53.369.581 
[91] Taniguchi, Y., Ohkawa, H., Masumoto, C., Fukuda, T., Tamai, T., Lee, K., et al. (2008) Overproduction of $\mathrm{C}_{4}$ Photosynthetic Enzymes in Transgenic Rice Plants: An Approach to Introduce the $\mathrm{C}_{4}$-Like Photosynthetic Pathway into Rice. Journal of Experimental Botany, 59, 1799-1809. http://dx.doi.org/10.1093/jxb/ern016

[92] Kathuria, H., Giri, J., Tyagi, H. and Tyagi, A.K. (2007) Advances in Transgenic Rice Biotechnology. Critical Reviews in Plant Sciences, 26, 65-103. http://dx.doi.org/10.1080/07352680701252809

[93] Bajaj, S. and Mohanty, A. (2005) Recent Advances in Rice Biotechnology-Towards Genetically Superior Transgenic Rice. Plant Biotechnology Journal, 3, 275-307. http://dx.doi.org/10.1111/j.1467-7652.2005.00130.x

[94] Ye, X., Al-Babili, S., Kloti, A., Zhang, J., Lucca, P. and Potrykus, I. (2000) Engineering the Provitamin A ( $\beta$-Carotene) Biosynthetic Pathway into (Carotinoid-Free) Rice Endosperm. Science, 287, 303-305. http://dx.doi.org/10.1126/science.287.5451.303

[95] Goto, F., Yoshihara, T., Shigemoto, N., Toki, S. and Takaiwa, F. (1999) Iron Fortification of Rice Seed by the Soybean Ferritin Gene. Nature Biotechnology, 17, 282-286. http://dx.doi.org/10.1038/7029

[96] Shen, H., Poovaiah, C.R., Ziebell, A., Tschaplinski, T.J., Pattathil, S., Gjersing, E., et al. (2013) Enhanced Characteristics of Genetically Modified Switchgrass (Panicum virgatum L.) for High Biofuel Production. Biotechnology for Biofuels, 6, 71. http://dx.doi.org/10.1186/1754-6834-6-71

[97] Chen, F. and Dixon, R.A. (2007) Lignin Modification Improves Fermentable Sugar Yields for Biofuel Production. Nature Biotechnology, 25, 759-761. http://dx.doi.org/10.1038/nbt1316

[98] Thurston, C.F. (1994) The Structure and Function of Fungal Laccases. Microbiology, 140, 19-26. http://dx.doi.org/10.1099/13500872-140-1-19

[99] Hood, E.E., Bailey, M.R., Beifuss, K., Magallanes-Lundback, M., Horn, M.E., Callaway, E., et al. (2003) Criteria for High Level Expression of a Fungal Laccase Gene in Transgenic Maize. Plant Biotechnology Journal, 1, 129-140. http://dx.doi.org/10.1046/j.1467-7652.2003.00014.x

[100] Dean, J.F.D. (2005) Synthesis of Lignin in Transgenic and Mutant Plants. In: Steinbuchel, A., Doi, Y. and Weinheim, D.E., Eds., Biotechnology of Biopolymers. From Synthesis to Patents, Wiley-VCH Verlag, Weinheim, 4-26.

[101] Baucher, M., Monties, B., Van Montagu, M. and Boerjan, W. (1998) Biosynthesis and Genetic Engineering of Lignin. Critical Reviews in Plant Sciences, 17, 125-197. http://dx.doi.org/10.1016/S0735-2689(98)00360-8

[102] Lapierre, C., Pollet, B., Petit-Conil, M., Toval, G., Romero, J., Pilate, G., et al. (1999) Structural Alterations of Lignins in Transgenic Poplars with Depressed Cinnamyl Alcohol Dehydrogenase or Caffeic Acid O-Methyltransferase Activity Have an Opposite Impact on the Efficiency of Industrial Kraft Pulping. Plant Physiology, 119, 153-164. http://dx.doi.org/10.1104/pp.119.1.153

[103] Madison, L.L. and Huisman, G.W. (1999) Metabolic Engineering of Poly(3-Hydroxyalkanoates): From DNA to Plastic. Microbiology and Molecular Biology Reviews, 63, 21-53.

[104] Arai, Y., Nakashita, H., Suzuki, Y., Kobayashi, Y., Shimizu, T., Yasuda, M., et al. (2002) Synthesis of a Novel Class of Polyhydroxyalkanoates in Arabidopsis Peroxisomes, and Their Use in Monitoring Short-Chain-Length Intermediates of $\beta$-Oxidation. Plant \& Cell Physiology, 43, 555-562. http://dx.doi.org/10.1093/pcp/pcf068

[105] Cahoon, E.B., Ripp, K.G., Hall, S.E. and Kinney, A.J. (2001) Formation of Conjugated $\Delta^{8}, \Delta^{10}$-Double Bonds by $\Delta^{12}$-Oleic Acid Desaturase-Related Enzymes. Biosynthetic Origin of Calendic Acid. The Journal of Biological Chemistry, 276, 2637-2643. http://dx.doi.org/10.1074/jbc.M009188200

[106] Broun, P. and Somerville, C. (1997) Accumulation of Ricinoleic, Lesquerolic, and Densipolic Acids in Seeds of Transgenic Arabidopsis Plants that Express a Fatty Acyl Hydroxylase cDNA from Castor Bean. Plant Physiology, 113, 933-942. http://dx.doi.org/10.1104/pp.113.3.933

[107] van de Loo, F.J., Broun, P., Turner, S. and Somerville, C. (1995) An Oleate 12-Hydroxylase from Ricinus communis L. Is a Fatty Acyl Desaturase Homolog. Proceedings of the National Academy of Sciences of the United States of America, 92, 6743-6747. http://dx.doi.org/10.1073/pnas.92.15.6743

[108] Singh, S.P., Zhou, X.R., Liu, Q., Stymne, S. and Green, A.G. (2005) Metabolic Engineering of New Fatty Acids in Plants. Current Opinion in Plant Biology, 8, 197-203. http://dx.doi.org/10.1016/j.pbi.2005.01.012

[109] Napier, J.A. (2007) The Production of Unusual Fatty Acids in Transgenic Plants. Annual Review of Plant Biology, 58, 295-319. http://dx.doi.org/10.1146/annurev.arplant.58.032806.103811

[110] McKeon, T.A. (2003) Genetically Modified Crops for Industrial Products and Processes and Their Affects on Human Health. Trends in Food Science and Technology, 14, 229-241. http://dx.doi.org/10.1016/S0924-2244(03)00071-2

[111] Berken, A., Mulholland, M.M., LeDuc, D.L. and Terry, N. (2002) Genetic Engineering of Plants to Enhance Selenium Phytoremediation. Critical Reviews in Plant Sciences, 21, 567-582. http://dx.doi.org/10.1080/0735-260291044368

[112] Eapen, S. and D’Souza, S.F. (2005) Prospects of Genetic Engineering of Plants for Phytoremediation of Toxic Metals. Biotechnology Advances, 23, 97-114. http://dx.doi.org/10.1016/j.biotechadv.2004.10.001 
[113] Eapen, S., Singh, S. and D’Souza, S. (2007) Advances in Development of Transgenic Plants for Remediation of Xenobiotic Pollutants. Biotechnology Advances, 25, 442-451. http://dx.doi.org/10.1016/j.biotechadv.2007.05.001

[114] Macek, T., Kotrba, P., Svatos, A., Novakova, M., Demnerova, K. and Mackova, M. (2008) Novel Roles for Genetically Modified Plants in Environmental Protection. Trends in Biotechnology, 26, 146-152. http://dx.doi.org/10.1016/j.tibtech.2007.11.009

[115] Doty, S.L. (2008) Enhancing Phytoremediation through the Use of Transgenics and Endophytes. New Phytologist, 179, 318-333. http://dx.doi.org/10.1111/j.1469-8137.2008.02446.x

[116] Vangronsveld, J., Herzig, R., Weyens, N., Boulet, J., Adriaensen, K., Ruttens, A., et al. (2009) Phytoremediation of Contaminated Soils and Groundwater: Lessons from the Field. Environmental Science and Pollution Research, 16, 765-794. http://dx.doi.org/10.1007/s11356-009-0213-6

[117] Kotrba, P., Najmanova, J., Macek, T., Ruml, T. and Mackova, M. (2009) Genetically Modified Plants in Phytoremediation of Heavy Metal and Metalloid Soil and Sediment Pollution. Biotechnology Advances, 27, 799-810. http://dx.doi.org/10.1016/j.biotechadv.2009.06.003

[118] Van Aken, B., Correa, P.A. and Schnoor, J.L. (2010) Phytoremediation of Polychlorinated Biphenyls: New Trends and Promises. Environmental Science and Technology, 44, 2767-2776. http://dx.doi.org/10.1021/es902514d

[119] Zhang, Y.W., Tam, N.F.Y. and Wong, Y.S. (2004) Cloning and Characterization of Type 2 Metallothionein-Like Gene from a Wetland Plant, Typha latifolia. Plant Science, 167, 869-877. http://dx.doi.org/10.1016/j.plantsci.2004.05.040

[120] Pilon-Smits, E.A.H., Hwang, S., Lytle, C.M., Zhu, Y., Tai, J.C., Bravo, R.C., et al. (1999) Overexpression of ATP Sulfurylase in Indian Mustard Leads to Increased Selenate Uptake, Reduction and Tolerance. Plant Physiology, 119, 123-132. http://dx.doi.org/10.1104/pp.119.1.123

[121] Van Huysen, T., Terry, N. and Pilon-Smits, E.A.H. (2004) Exploring the Selenium Phytoremediation Potential of Transgenic Indian Mustard Overexpressing ATP Sulfurylase or Cystathionine- $\gamma$-Synthase. International Journal of Phytoremediation, 6, 111-118. http://dx.doi.org/10.1080/16226510490454786

[122] Cobbett, C. and Goldsbrough, P. (2002) Phytochelatins and Metallothioneins: Roles in Heavy Metal Detoxification and Homeostasis. Annual Review of Plant Biology, 53, 159-182. http://dx.doi.org/10.1146/annurev.arplant.53.100301.135154

[123] Kawashima, C.G., Noji, M., Nakamura, M., Ogra, Y., Suzuki, K.T. and Saito, K. (2004) Heavy Metal Tolerance of Transgenic Tobacco Plants Over-Expressing Cysteine Synthase. Biotechnology Letters, 26, 153-157. http://dx.doi.org/10.1023/B:BILE.0000012895.60773.ff

[124] Tong, Y.P., Kneer, R. and Zhu, Y.G. (2004) Vacuolar Compartmentalization: A Second-Generation Approach to Engineering Plants for Phytoremediation. Trends in Plant Science, 9, 7-9. http://dx.doi.org/10.1016/j.tplants.2003.11.009

[125] Cherian, S. and Oliveira, M.M. (2005) Transgenic Plants in Phytoremediation: Recent Advances in New Possibilities. Environmental Science and Technology, 39, 9377-9390. http://dx.doi.org/10.1021/es051134l

[126] Misra, S. and Gedamu, L. (1989) Heavy Metal Tolerant Transgenic Brassica napus L. and Nicotiana tabacum L. Plants. Theoretical and Applied Genetics, 78, 161-168. http://dx.doi.org/10.1007/BF00288793

[127] Pan, A., Yang, M., Tie, F., Li, L., Chen, Z. and Ru, B. (1994) Expression of Mouse Metallothionein-I Gene Confers Cadmium Resistance in Transgenic Tobacco Plants. Plant Molecular Biology, 24, 341-351. http://dx.doi.org/10.1007/BF00020172

[128] Hasegawa, I., Terada, E., Sunairi, M., Wakita, H., Shinmachi, F., Noguchi, A., et al. (1997) Genetic Improvement of Heavy Metal Tolerance in Plants by Transfer of the Yeast Metallothionein Gene (CUP1). Plant and Soil, 196, $277-281$. http://dx.doi.org/10.1023/A:1004222612602

[129] Evans, K.M., Gatehouse, J.A., Lindsay, W.P., Shi, J., Tommey, A.M. and Robinson, N.J. (1992) Expression of the Pea Metallothionein-Like Gene PsMT $T_{\mathrm{A}}$ in Escherichia coli and Arabidopsis thaliana and Analysis of Trace Metal Ion Accumulation: Implications for PsMT Function. Plant Molecular Biology, 20, 1019-1028. http://dx.doi.org/10.1007/BF00028889

[130] Zhu, Y., Pilon-Smits, E.A.H., Tarun, A., Weber, S.U., Jouanin, L. and Terry, N. (1999) Cadmium Tolerance and Accumulation in Indian Mustard Is Enhanced by Overexpressing $\gamma$-Glutamylcysteine Synthetase. Plant Physiology, 121, 1169-1177. http://dx.doi.org/10.1104/pp.121.4.1169

[131] Arisi, A.C.M., Noctor, G., Foyer, C.H. and Jouanin, L. (1997) Modification of Thiol Contents in Poplars (Populus tremula $\times$ P. alba) Overexpressing Enzymes Involved in Glutathione Synthesis. Planta, 203, 362-373. http://dx.doi.org/10.1007/s004250050202

[132] Bizily, S.P., Rugh, C.L., Summers, A.O. and Meagher, R.B. (1999) Phytoremediation of Methylmercury Pollution: merB Expression in Arabidopsis thaliana Confers Resistance to Organomercurials. Proceedings of the National Academy of Sciences of the United States of America, 96, 6808-6813. http://dx.doi.org/10.1073/pnas.96.12.6808 
[133] Rugh, C.L., Wilde, H.D., Stack, N.M., Thompson, D.M., Summers, A.O. and Meagher, R.B. (1996) Mercuric Ion Reduction and Resistance in Transgenic Arabidopsis thaliana Plants Expressing a Modified Bacterial merA Gene. Proceedings of the National Academy of Sciences of the United States of America, 93, 3182-3187. http://dx.doi.org/10.1073/pnas.93.8.3182

[134] LeDuc, D.L., Tarun, A.S., Montes-Bayon, M., Meija, J., Malit, M.F., Wu, C.P., et al. (2004) Overexpression of Selenocysteine Methyltransferase in Arabidopsis and Indian Mustard Increases Selenium Tolerance and Accumulation. Plant Physiology, 135, 377-383. http://dx.doi.org/10.1104/pp.103.026989

[135] French, C.E., Rosser, S.J., Davies, G.J., Nicklin, S. and Bruce, N.C. (1999) Biodegradation of Explosives by Transgenic Plants Expressing Pentaerythritol Tetranitrate Reductase. Nature Biotechnology, 17, 491-494. http://dx.doi.org/10.1038/8673

[136] Gullner, G., Komives, T. and Rennenberg, H. (2001) Enhanced Tolerance of Transgenic Poplar Plants Overexpressing $\gamma$-Glutamylcysteine Synthetase towards Chloroacetanilide Herbicides. Journal of Experimental Botany, 52, 971-979. http://dx.doi.org/10.1093/jexbot/52.358.971

[137] Flocco, C.G., Lindblom, S.D., Elizabetha, A.H. and Smits, P. (2004) Overexpression of Enzymes Involved in Glutathione Synthesis Enhances Tolerance to Organic Pollutants in Brassica juncea. International Journal of Phytoremediation, 6, 289-304. http://dx.doi.org/10.1080/16226510490888811

[138] Ohkawa, H., Imaishi, H., Shiota, N., Yamada, T. and Inui, H. (1999) Cytochrome P450s and Other Xenobiotic Metabolizing Enzymes in Plants. In: Brooks, J.T. and Roberts, T.R., Eds., Pesticide Chemistry and Biosciences: The Food-Environment Challenge, Royal Society of Chemistry, Cambridge, 259-264.

[139] Inui, H., Kodama, T., Ohkawa, Y. and Ohkawa, H. (2000) Herbicide Metabolism and Cross-Tolerance in Transgenic Potato Plants Co-Expressing Human CYP1A1, CYP2B6 and CYP2C19. Pesticide Biochemistry and Physiology, 66, 116-129. http://dx.doi.org/10.1006/pest.1999.2454

[140] Protalix Biotherapeutics (2014) http://www.genengnews.com/gen-news-highlights/protalix-pfizer-report-fda-approval-of-plant-derived-b-gaucher-b/81 $\underline{246710 /}$

[141] Union of Concerned Scientists (2006) Position Paper: Pharmaceutical and Industrial Crops. http://www.ucsusa.org

[142] Liénard, D., Sourrouille, C., Gomord, V. and Faye, L. (2007) Pharming and Transgenic Plants. Biotechnology Annual Review, 13, 115-147. http://dx.doi.org/10.1016/S1387-2656(07)13006-4

[143] Walsh, G. and Jefferis, R. (2006) Post-Translational Modifications in the Context of Therapeutic Proteins. Nature Biotechnology, 24, 1241-1252. http://dx.doi.org/10.1038/nbt1252

[144] Gomord, V. and Faye, L. (2004) Posttranslational Modification of Therapeutic Proteins in Plants. Current Opinion in Plant Biology, 7, 171-181. http://dx.doi.org/10.1016/j.pbi.2004.01.015

[145] Saklani, A. and Kutty, S.K. (2008) Plant-Derived Compounds in Clinical Trials. Drug Discovery Today, 13, $161-171$. http://dx.doi.org/10.1016/j.drudis.2007.10.010

[146] Ma, J.K., Hiatt, A., Hein, M., Vine, N.D., Wang, F., Stabila, P., et al. (1995) Generation and Assembly of Secretory Antibodies in Plants. Science, 268, 716-719. http://dx.doi.org/10.1126/science.7732380

[147] Khoudi, H., Laberge, S., Ferullo, J.M., Bazin, R., Darveau, A., Castonguay, Y., et al. (1999) Production of a Diagnostic Monoclonal Antibody in Perennial Alfalfa Plants. Biotechnology and Bioengineering, 64, 135-143. http://dx.doi.org/10.1002/(SICI)1097-0290(19990720)64:2<135::AID-BIT2>3.3.CO;2-H

[148] Gomord, V., Chamberlin, P., Jefferis, R. and Faye, L. (2005) Biopharmaceutical Production in Plants: Problems, Solutions, and Opportunities. Trends in Biotechnology, 23, 559-565. http://dx.doi.org/10.1016/j.tibtech.2005.09.003

[149] Perlak, F.J., Fuchs, R.L., Dean, D.A., McPherson, S.L. and Fischhoff, D.A. (1991) Modification of the Coding Sequence Enhances Plant Expression of Insect Control Protein Genes. Proceedings of the National Academy of Sciences of the United States of America, 88, 3324-3328. http://dx.doi.org/10.1073/pnas.88.8.3324

[150] Batard, Y., Hehn, A., Nedelkina, S., Schalk, M., Pallet, K., Schaller, H., et al. (2000) Increasing Expression of P450 and P450-Reductase Proteins from Monocots in Heterologous Systems. Archives of Biochemistry and Biophysics, 379, 161-169. http://dx.doi.org/10.1006/abbi.2000.1867

[151] Hamada, A., Yamaguchi, K.I., Ohnishi, N., Harada, M., Nikumaru, S. and Honda, H. (2005) High Level Production of Yeast (Schwanniomyces occidentalis) Phytase in Transgenic Rice Plants by a Combination of Signal Sequence and Codon Modification of the Phytase Gene. Plant Biotechnology Journal, 3, $43-55$.

[152] Scholthof, H.B., Scholthof, K.B. and Jackson, A.O. (1995) Identification of Tomato Bushy Stunt Virus Host-Specific Symptom Determinants by Expression of Individual Genes from a Potato Virus X Vector. The Plant Cell, 7, 11571172. http://dx.doi.org/10.1105/tpc.7.8.1157

[153] Voinnet, O., Rivas, S., Mestre, P. and Baulcombe, D. (2003) An Enhanced Transient Expression System in Plants 
Based on Suppression of Gene Silencing by p19 Protein of Tomato Bushy Stunt Virus. The Plant Journal, 33, 949-956. http://dx.doi.org/10.1046/j.1365-313X.2003.01676.x

[154] Komarnytsky, S., Borisjuk, N., Yakoby, N., Garvey, A. and Raskin, I. (2006) Cosecretion of Protease Inhibitor Stabilizes Antibodies Produced by Plant Roots. Plant Physiology, 141, 1185-1193. http://dx.doi.org/10.1104/pp.105.074419

[155] Drake, P.M., Chargelegue, D.M., Vine, N.D., van Dolleweerd, C.J., Obregon, P. and Ma, J.K. (2003) Rhizosecretion of a Monoclonal Antibody Protein Complex from Transgenic Tobacco Roots. Plant Molecular Biology, 52, $233-241$. http://dx.doi.org/10.1023/A:1023909331482

[156] Arcalis, E., Marcel, S., Altmann, F., Kolarich, D., Drakakaki, G., Fischer, R., et al. (2004) Unexpected Deposition Patterns of Recombinant Proteins in Post-Endoplasmic Reticulum Compartments of Wheat Endosperm. Plant Physiology, 136, 3457-3466. http://dx.doi.org/10.1104/pp.104.050153

[157] Nykiforuk, C.L., Booth, J.G., Murray, E.W., Keon, R.G., Goren, H.J., Markley, N.A. and Moloney, M.M. (2006) Transgenic Expression and Recovery of Biologically Active Recombinant Human Insulin from Arabidopsis thaliana Seeds. Plant Biotechnology Journal, 4, 77-85. http://dx.doi.org/10.1111/j.1467-7652.2005.00159.x

[158] Faye, L. and Daniell, H. (2006) Novel Pathway for Glycoprotein Import into Chloroplasts. Plant Biotechnology Journal, 19, 71-74.

[159] Bardor, M., Faveeuw, C., Gilbert, A.C., Gilbert, D., Galas, L., Trottein, F., et al. (2003) Immunoreactivity in Mammals of Two Typical Plant Glyco-Epitopes, Cor- $\alpha(1,3)$-Fucose and Core Xylose. Glycobiology, 13, 427-434. http://dx.doi.org/10.1093/glycob/cwg024

[160] Gomord, V., Sourouille, C., Fitchette, A.C., Bador, M., Pagny, S., Lerouge, P. and Faye, L. (2004) Production and Glycosylation of Plant-Made Pharmaceuticals: The Antibody as a Challenge. Plant Biotechnology Journal, 2, 83-100. http://dx.doi.org/10.1111/j.1467-7652.2004.00062.x

[161] Sriraman, R., Bardor, M., Sack, M., Vaquero, C., Faye, L., Fischer, R., et al. (2004) Recombinant Anti-hCG Antibodies Retained in the Endoplasmic Reticulum of Transformed Plants Lack Core Xylose and Core- $\alpha(1,3)$-fucose Residues. Plant Biotechnology Journal, 2, 279-287. http://dx.doi.org/10.1111/j.1467-7652.2004.00078.x

[162] Triguero, A., Cabrera, G., Cremata, J., Yuen, C.T., Wheeler, J. and Ramirez, N.I. (2005) Plant-Derived Mouse lgG Monoclonal Antibody Fused to KDEL Endoplasmic Reticulum-Retention Signal Is $N$-glycosylated Homogenously throughout the Plant and Mostly High-Mannose Type N-glycans. Plant Biotechnology Journal, 3, 449-457. http://dx.doi.org/10.1111/j.1467-7652.2005.00137.X

[163] Palacpac, N.Q., Yoshida, S., Sakai, H., Kimura, Y., Fujiyama, K., Yoshida, T. and Seki, T. (1999) Stable Expression of Human $\beta 1$,4-galactosyltransfrase in Plant Cells Modifies N-Linked Glycosylation Patterns. Proceedings of the National Academy of Sciences of the United States of America, 96, 4692-4697. http://dx.doi.org/10.1073/pnas.96.8.4692

[164] Bakker, H., Bardor, M., Molhoff, J., Gomord, V., Elbers, I., Stevens, L., et al. (2001) Humanized Glycans on Antibodies Produced by Transgenic Plants. Proceedings of the National Academy of Sciences of the United States of America, 98, 2899-2904. http://dx.doi.org/10.1073/pnas.031419998

[165] Protalix Biotherapeutics (2014) http://www.protalix.com/products/elelyso-taliglucerase-alfa.asp

[166] Protalix Biotherapeutics (2014) http://www.protalix.com/development-pipeline/prx-102-fabry-disease.asp

[167] Protalix Biotherapeutics (2014) http://www.thestreet.com/story/11306621/1/protalixs-acetylcholinesterase-demonstrates-potential-role-in-the-treatment -of-parkinsons-disease.html

[168] SemiBioSys Genetics (2014) http://www.semibiosys.com

[169] Agragen http://www.plantpharma.org

[170] USDA-APHIS (2014) http://www.aphis.usda.gov/biotechnology/about.shtml

[171] FAO (Food and Agriculture Organization) (2009) http://www.fao.org

[172] King, C., Purcell, L. and Vories, E. (2001) Plant Growth and Nitrogenase Activity of Glyphosate-Tolerant Soybean in Response to Foliar Glyphosate Applications. Agronomy Journal, 93, 179-186. http://dx.doi.org/10.2134/agronj2001.931179x

[173] Hohn, B., Levy, A.A. and Puchta, H. (2001) Elimination of Selection Markers from Transgenic Plants. Current Opinion in Biotechnology, 12, 139-143. http://dx.doi.org/10.1016/S0958-1669(00)00188-9

[174] Zuo, J.R., Niu, Q.W., Moller, S.G. and Chua, N.H. (2001) Chemical-Regulated, Site-Specific DNA Excision in Transgenic Plants. Nature Biotechnology, 19, 157-161. http://dx.doi.org/10.1038/84428

[175] Goedeke, S., Hensel, G., Kapusi, E., Gahrtz, M. and Kumlehn, J. (2007) Transgenic Barley in Fundamental Research and Biotechnology. Transgenic Plant Journal, 1, 104-117.

[176] Keenan, R.J. and Stemmer, W.P.C. (2002) Nontransgenic Crops from Transgenic Plants. Nature Biotechnology, 20, 
215-216. http://dx.doi.org/10.1038/nbt0302-215

[177] Daniell, H. (2002) Molecular Strategies for Gene Containment in Transgenic Crops. Nature Biotechnology, 20, 581-586. http://dx.doi.org/10.1038/nbt0602-581

[178] Kuvshinov, V., Koivu, K., Kanerva, A. and Pehu, E. (2001) Molecular Control of Transgene Escape from Genetically Modified Plants. Plant Science, 160, 517-522. http://dx.doi.org/10.1016/S0168-9452(00)00414-3

[179] Avni, A. and Edelman, M. (1991) Direct Selection for Parental Inheritance of Chloroplasts in Sexual Progeny of Nicotiana. Molecular and General Genetics, 225, 273-277. http://dx.doi.org/10.1007/BF00269859

[180] Corriveau, J.P. and Coleman, A.W. (1988) Rapid Screening Method to Detect Potential Biparental Inheritance of Plastid DNA and Results for over 200 Angiosperm Species. American Journal of Botany, 75, 1443-1458. http://dx.doi.org/10.2307/2444695

[181] Wang, T., Li, Y., Shi, Y., Reboud, X., Darmency, H. and Gressel, J. (2004) Low Frequency Transmission of a PlastidEncoded Trait in Setaria italica. Theoretical and Applied Genetics, 108, 315-320. http://dx.doi.org/10.1007/s00122-003-1424-8

[182] Huang, C.Y., Ayliffe, M.A. and Timmis, J.N. (2003) Direct Measurement of the Transfer Rate of Chloroplast DNA into the Nucleus. Nature, 408, 796-815.

[183] Singh, D.P., Jermakkow, A.M. and Swain, S.M. (2007) Preliminary Development of a Genetic Strategy to Prevent Transgene Escape by Blocking Effective Pollen Flow from Transgenic Plants. Functional Plant Biology, 34, 1055-1060. http://dx.doi.org/10.1071/FP06323

[184] Monsanto (2005) Annual Report for Fiscal Year Ended August 31, Form 10-K. U.S. Securities and Exchange Commission, Washington DC. http://www.monsanto.com/investors/documents/pubs/2005/mon_2005_10-k.pdf

[185] McDougall, P. (2011) The Cost and Time Involved in the Discovery, Development and Authorisation of a New Plant Biotechnology Derived Trait. Consultancy Study for Crop Life International by P McDougall, Midlothian, 1-24. 
Scientific Research Publishing (SCIRP) is one of the largest Open Access journal publishers. It is currently publishing more than 200 open access, online, peer-reviewed journals covering a wide range of academic disciplines. SCIRP serves the worldwide academic communities and contributes to the progress and application of science with its publication.

Other selected journals from SCIRP are listed as below. Submit your manuscript to us via either submit@scirp.org or Online Submission Portal.
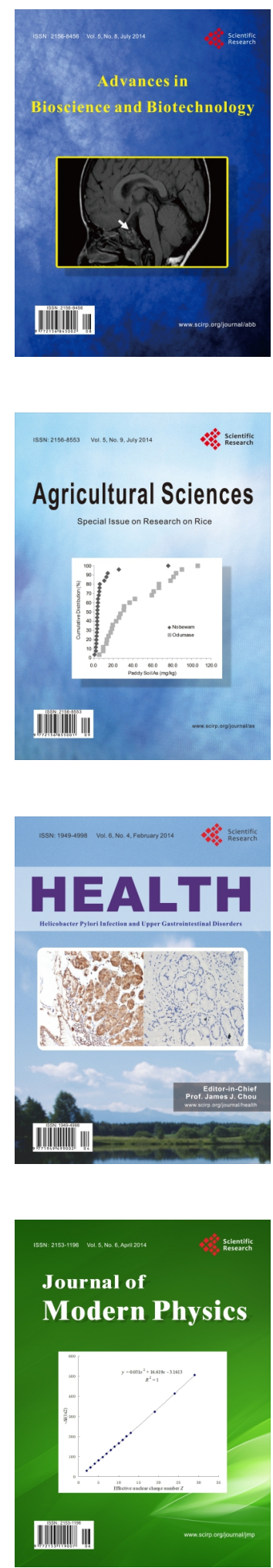
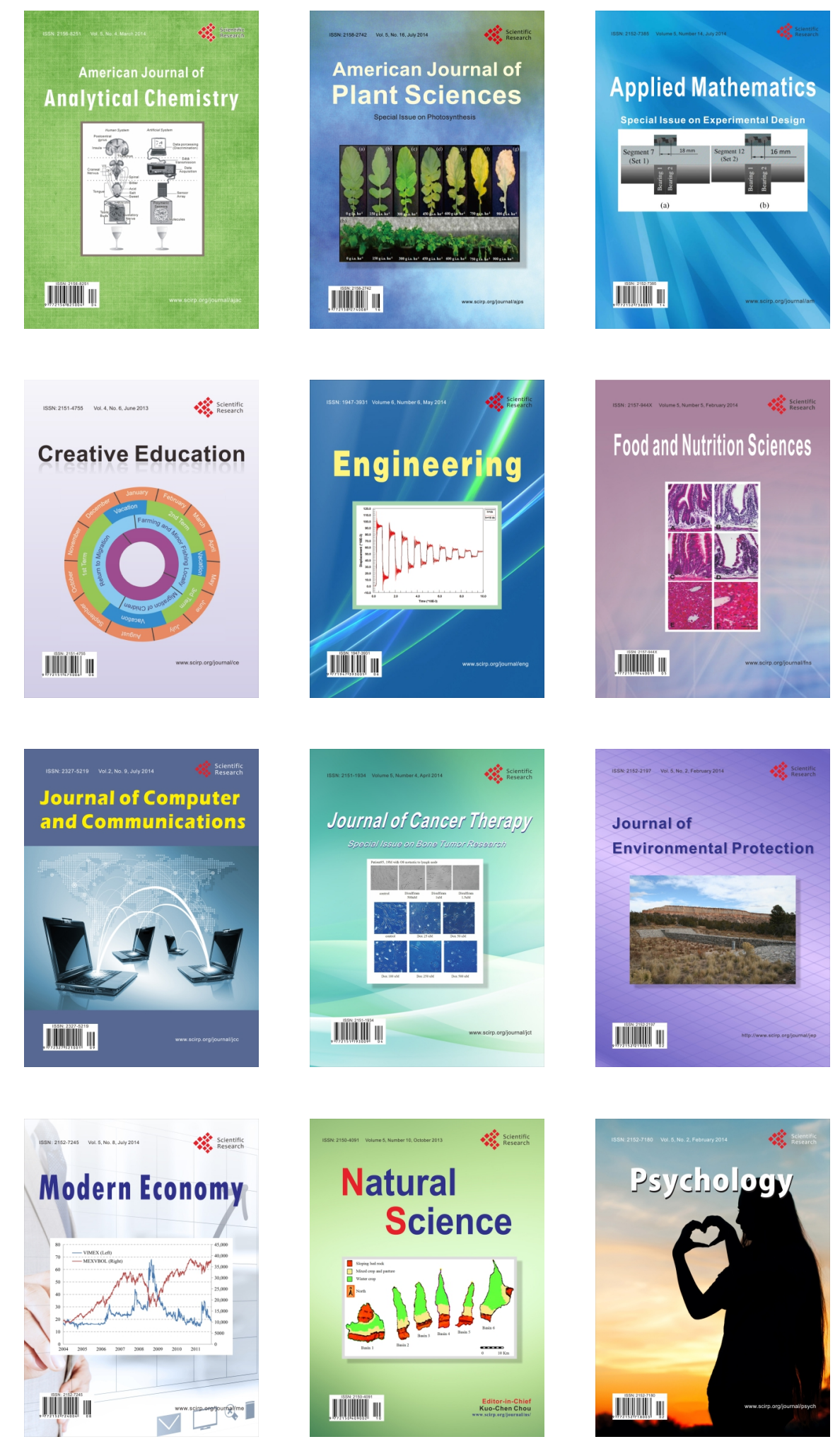